Licenciatura em Administração de Unidades de Saúde

\title{
Saúde Clínica e Saúde Pública
}

II $\underline{\underline{a}}$ sessão

Apresentação

Denise Capela dos Santos

Lisboa, Outubro de 2018

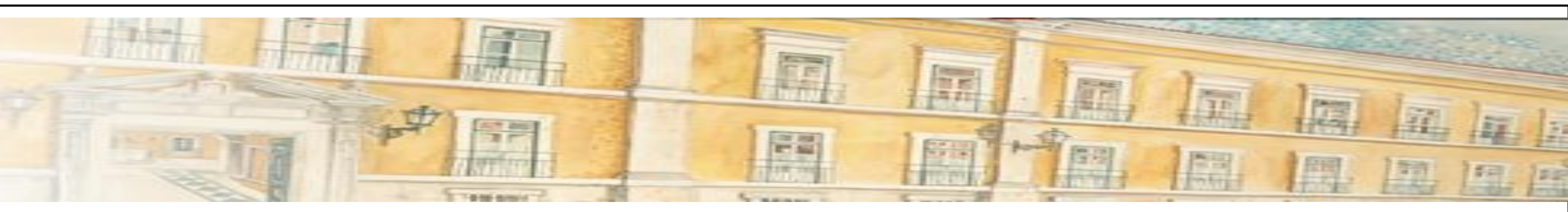




\section{Objectivos pedagógicos da disciplina}

- Identificar conceito e objetivos da saúde pública;

- Saber perspetivar o principais problemas de saúde e seus determinantes, numa lógica de saúde pública;

- Conhecer a organização da saúde pública em Portugal, enquanto prática profissional;

- Conhecer as principais áreas de intervenção em saúde pública;

- Analisar a importância da prática da saúde pública na administração em saúde. 
- Saúde e Saúde Pública: conceitos e evolução geral;

- Âmbito da Saúde Pública: conceitos, princípios e fundamentos;

- A evolução dos problemas de saúde e seus fatores determinantes, em Portugal e no Mundo;

- Organização dos Serviços de Saúde Pública em Portugal;

- Áreas de aplicação em saúde pública:

$\checkmark$ Medição e Indicadores de saúde;

$\checkmark$ Monitorização do estado de saúde;

$\checkmark \quad$ Planeamento estratégico em saúde;

$\checkmark$ Avaliação de impacto em saúde;

$\checkmark$ Vigilância epidemiológica;

$\checkmark \quad$ Análise e gestão do risco;

$\checkmark$ Gestão de programas e projetos de promoção e proteção da saúde;

$\checkmark \quad$ Investigação em saúde pública.

- A saúde pública do futuro integrada na gestão de unidades de saúde.

- A saúde clínica

- Sistemas do corpo humano e serviços hospitalares

- Causalidade da doença

- Ensaios clínicos e segurança de pacientes nas unidades de saúde 


\section{Saúde Clínica e Saúde Pública} $2^{\underline{a}}$ sessão:

\section{O corpo humano}

Denise Capela dos Santos

Lisboa, 2018 


\section{Sumário}

O conceito de saúde

Sistemas do corpo humano

Serviços hospitalares

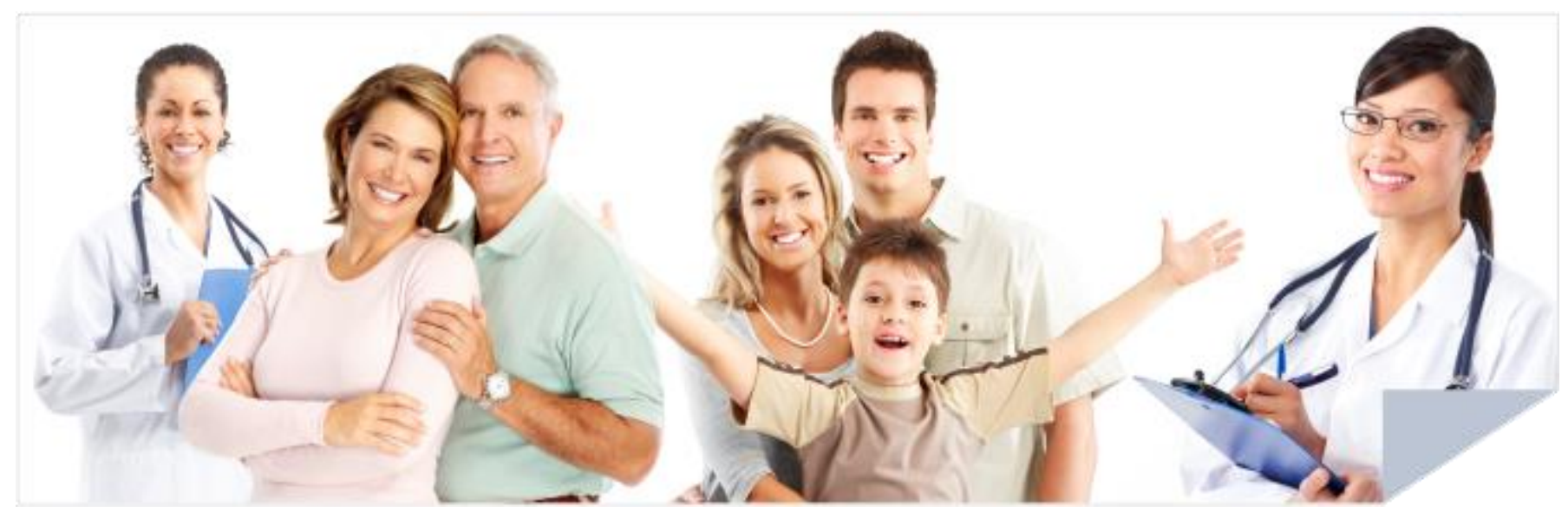




\section{Sistemas do Corpo Humano}

Um sistema é um conjunto de órgãos com determinada função.
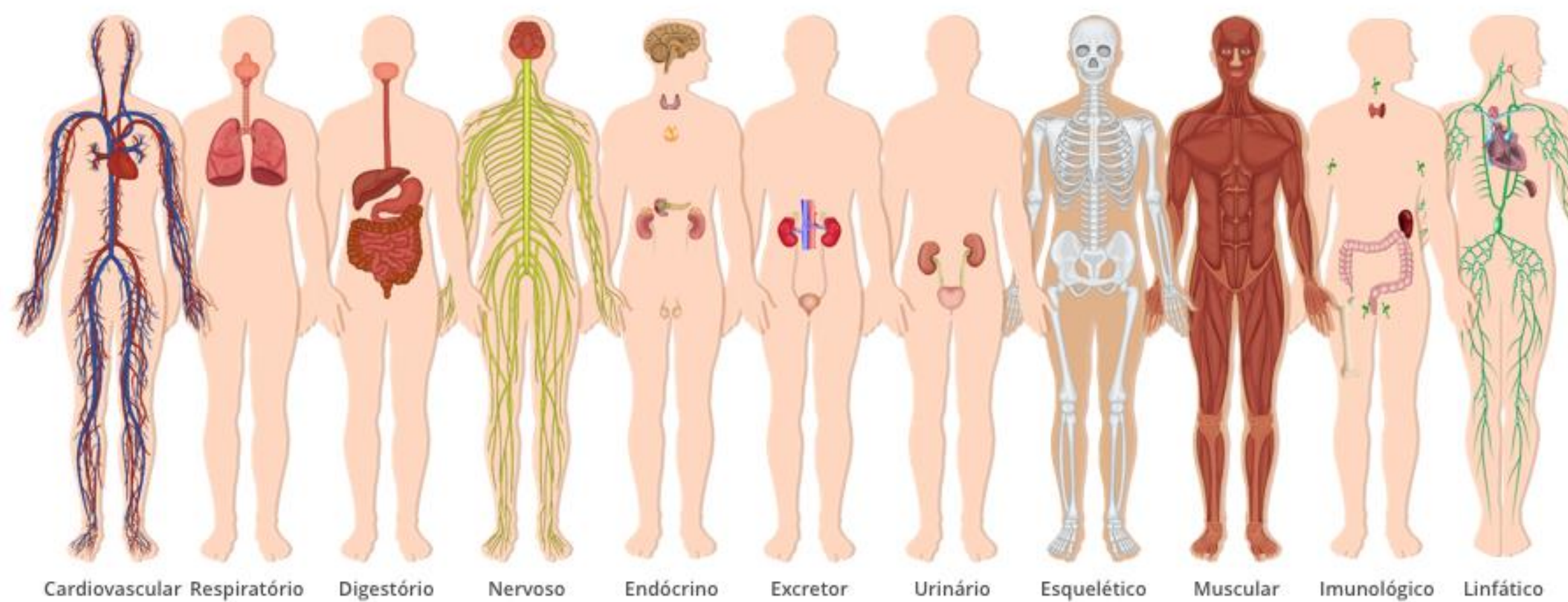


\section{Sistema circulatório ou cardiovascular}

Responsável pela circulação sanguínea e aporte de 02, nutrientes e hormonas

- Coração

- Artérias

- Veias

- Vasos Capilares

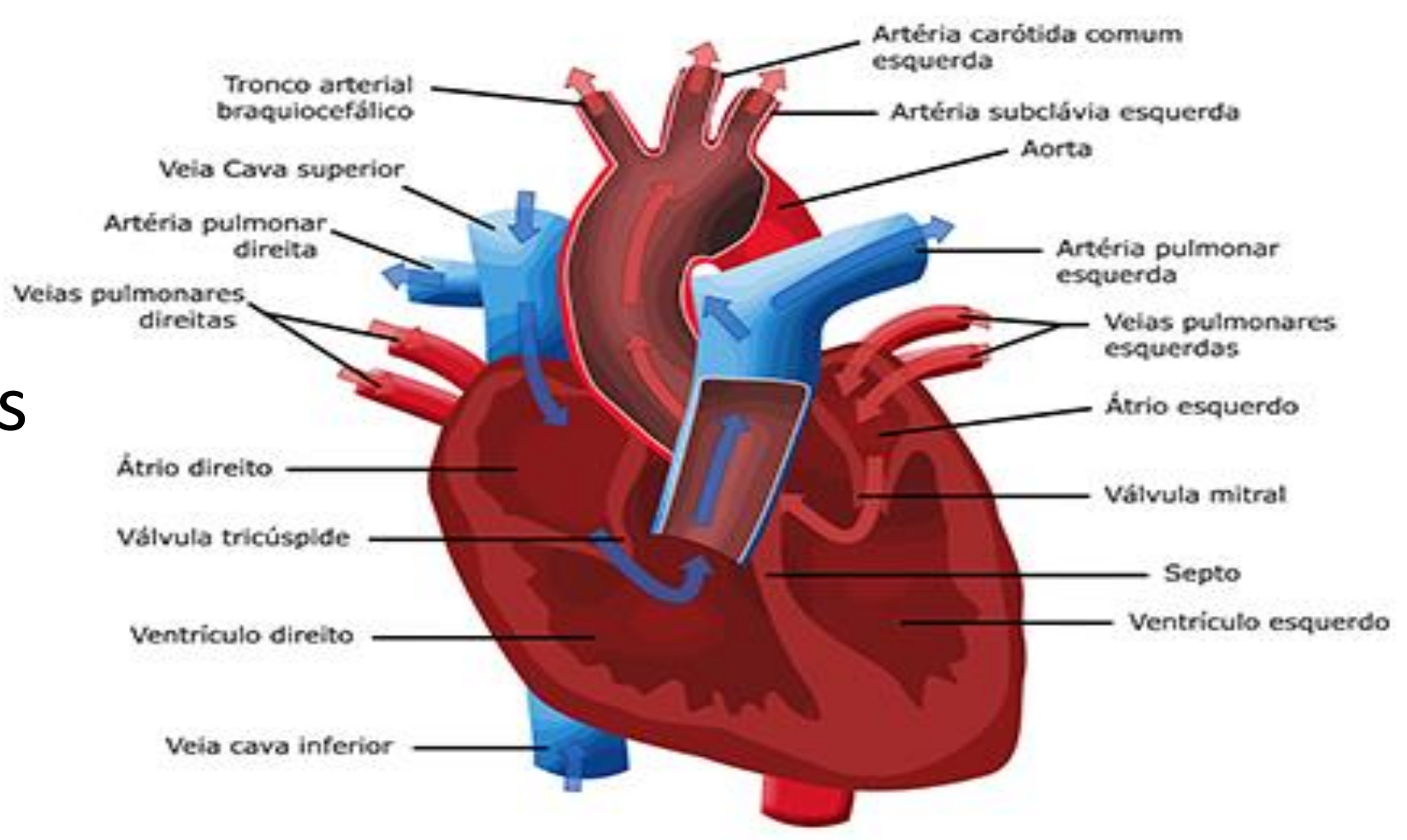




\section{Sistema circulatório ou}

\section{cardiovascular}

Componentes do Sangue:

Hemácias/ eritrócitos: Hemoglobina,

O2 (medula óssea)

Leucócitos: neutrófilos, eosinófilos,

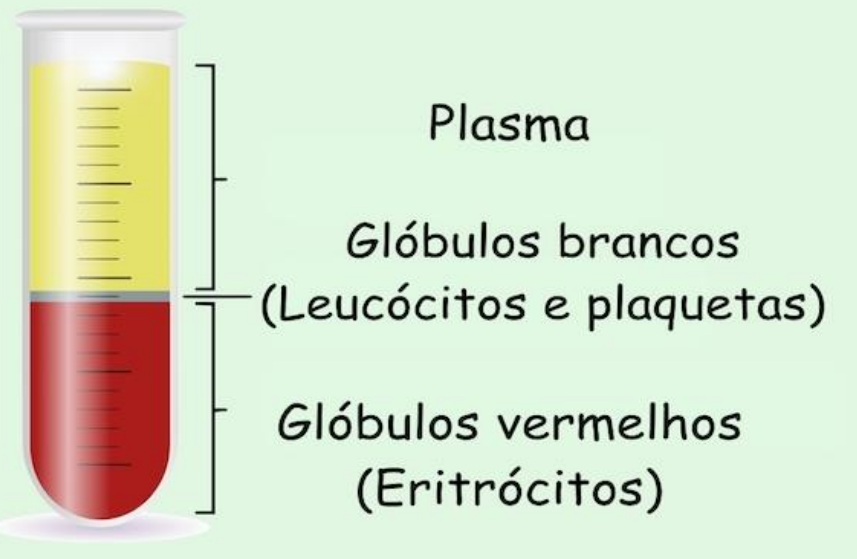

basófilos, linfócitos,

monócitos

Plaquetas: coagulação (hemofilia/trombose)

90\% Plasma: H2O, Proteínas,

enzimas e sais minerais,

$\mathrm{CO} 2$, toxinas (fígado) 


\section{Sistema circulatório ou \\ cardiovascular}

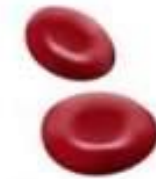

Hemácios
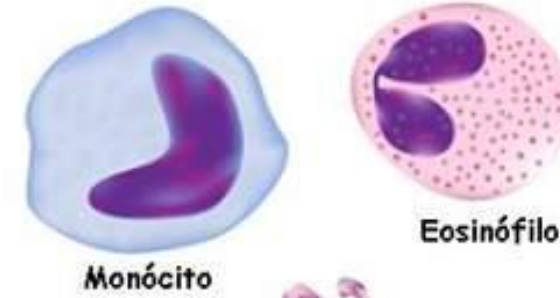

Leucócitos/glóbulos brancos:

1. Neutrófilos, combate inflamação

causada por uma bactéria ou fungo, pús

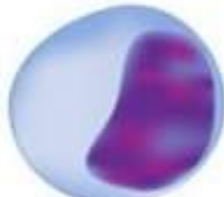

Linfócito

Plaquetas

2. Eosinófilos, combate parasitas e reações

alérgicas

3. Basófilos, combatem bactérias e reações

alérgicas e fazem vasodilatação

4. Linfócitos, produzem anticorpos e

Combatem células cancerosas - linfa, células B e T

5. Monócitos, fagocitose e apresentação de parte do invasor aos linfócitos T 
O sistema imunológico é composto por um conjunto de elementos do corpo humano que trabalham juntos para o defender de corpos estranhos.

- Resposta imunitária inata:

- Barreiras físicas e mecânicas: pele, trato respiratório, membranas, mucosas, fluidos corporais, tosse, espirro.

- Barreiras fisiológicas temperatura corporal e à acidez do trato gastrointestinal

- Barreiras celulares: Fagocitam (macrófagos e monócitos)

- Barreira inflamatória: Reação a infecções com danos tecidulares; induzem células fagocitárias para a área afetada.

- Resposta imunitária adquirida:

- Linfócitos B - Anticorpos (Ag fora célula)

- Linfócitos T - (Intracelulares + Memória)

- Vacinas, Ac maternos

- Baço + Linfonodos - aglomerados, início da resposta imunitária adquirida

- Outros - produção

\section{Sistema}

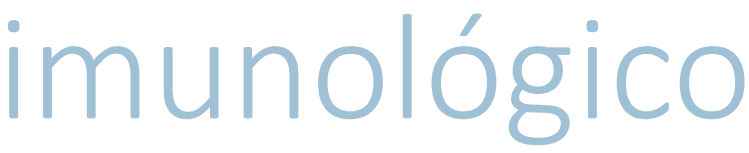

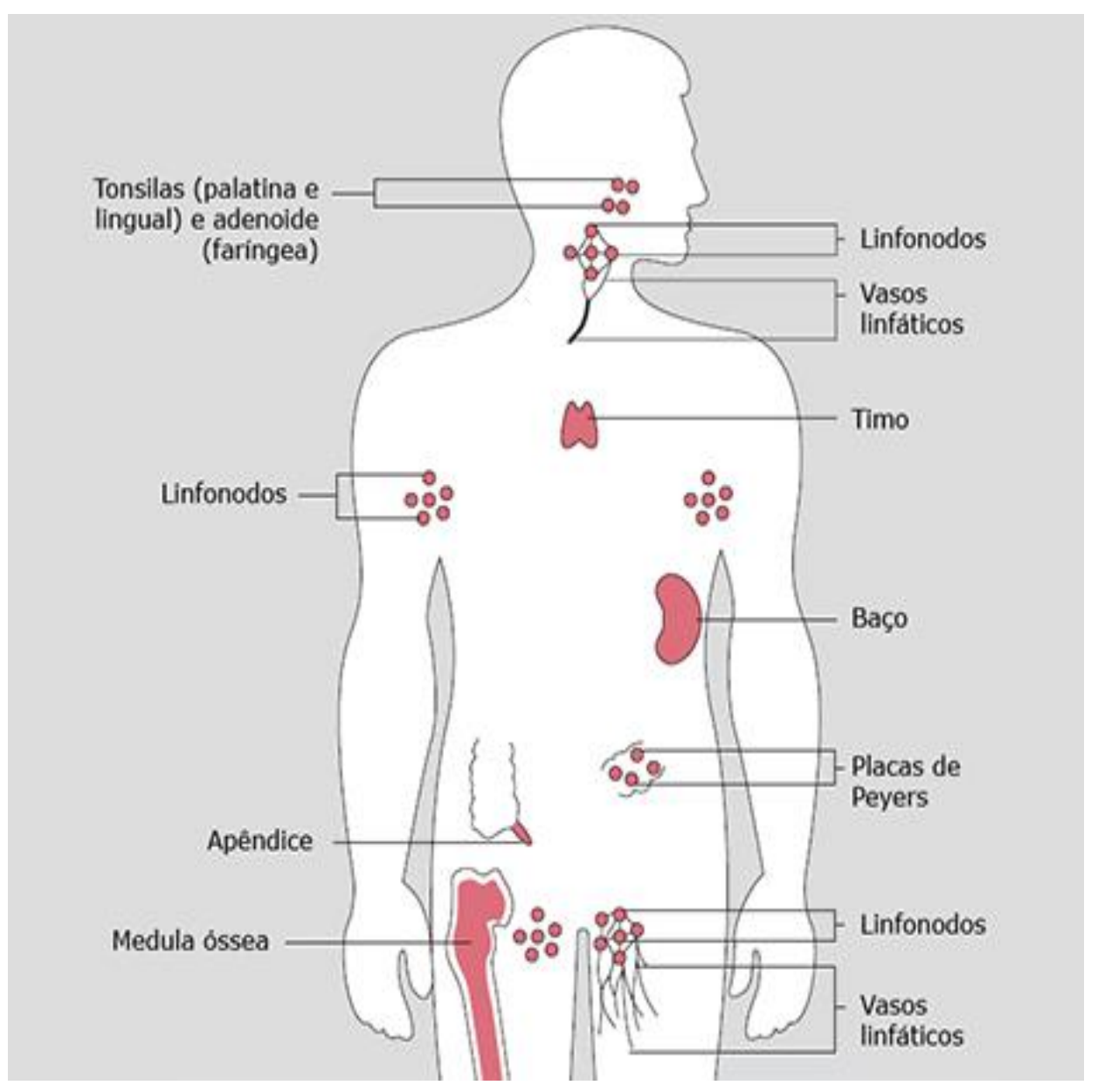




\section{Sistema respiratório}

Responsável pela respiração

(absorção de $\mathrm{O} 2$ e libertação de CO2)

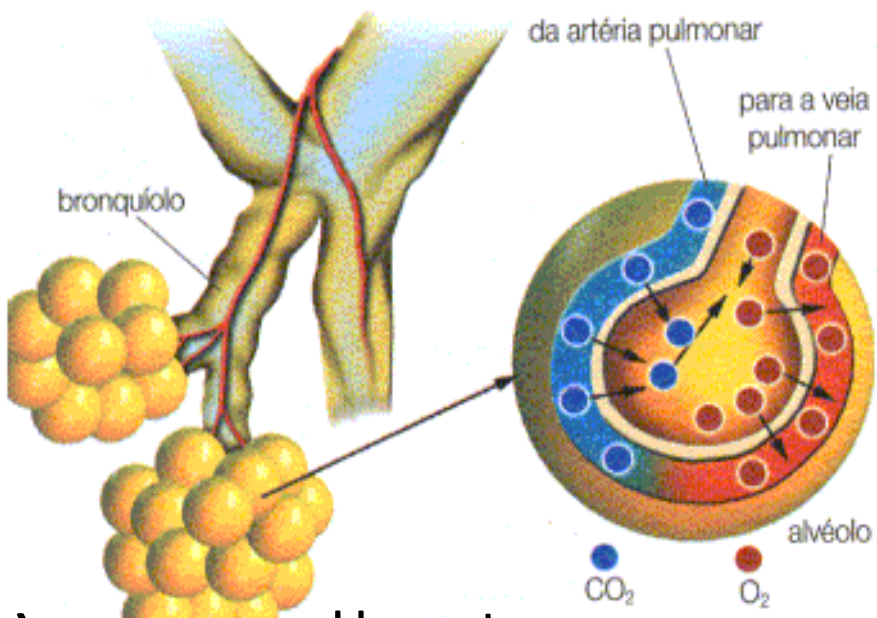

- Cavidade Nasal

- Faringe

- Laringe

- Traqueia

- Brônquios

- Pulmões

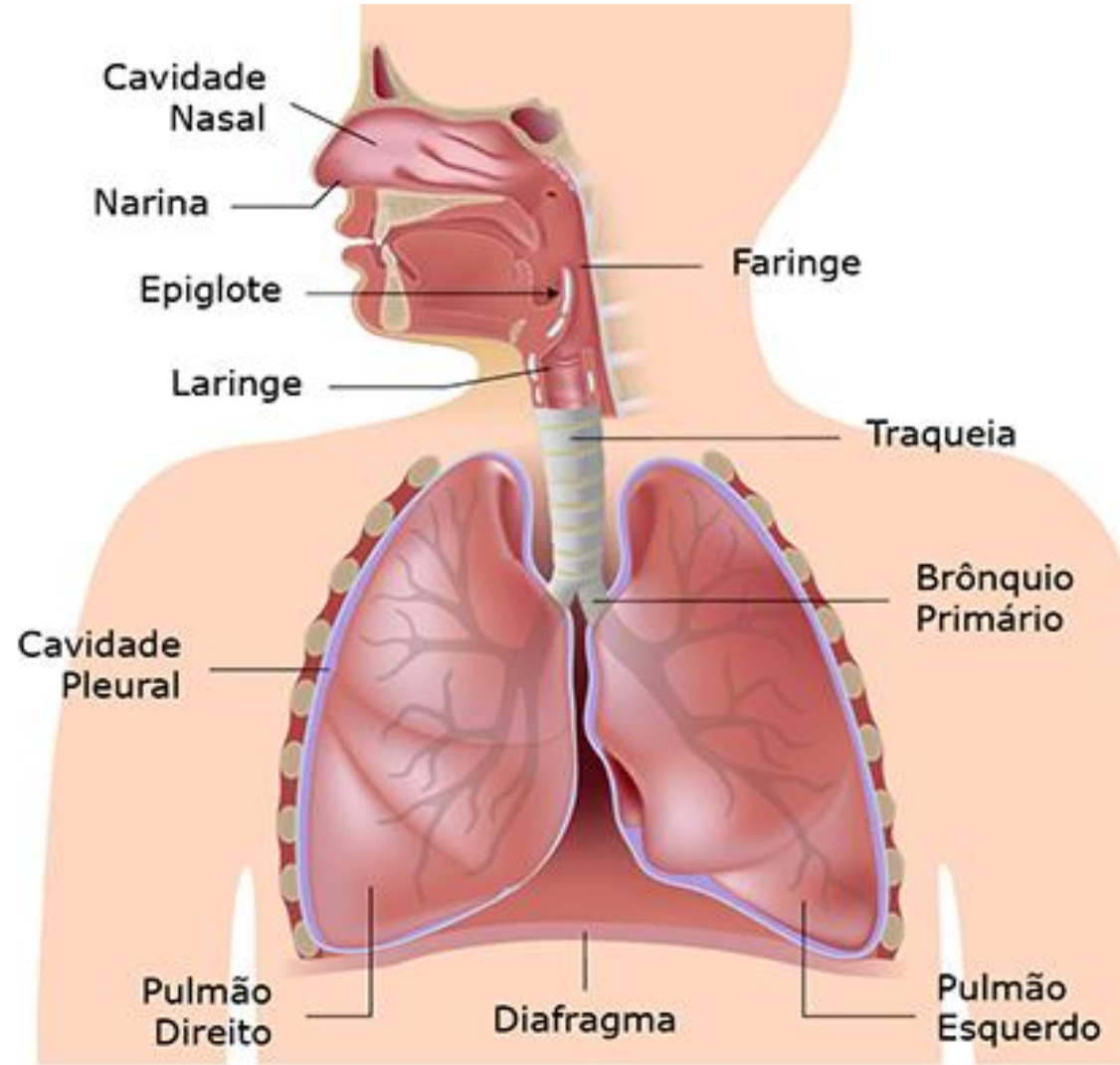


É uma complexa rede de vasos que transporta a linfa pelo corpo. Em conjunto com o sistema imunológico, o sistema linfático ajuda a proteger as células imunes. Além disso, é responsável pela absorção dos ácidos gordos e pelo equilíbrio dos fluídos nos tecidos.

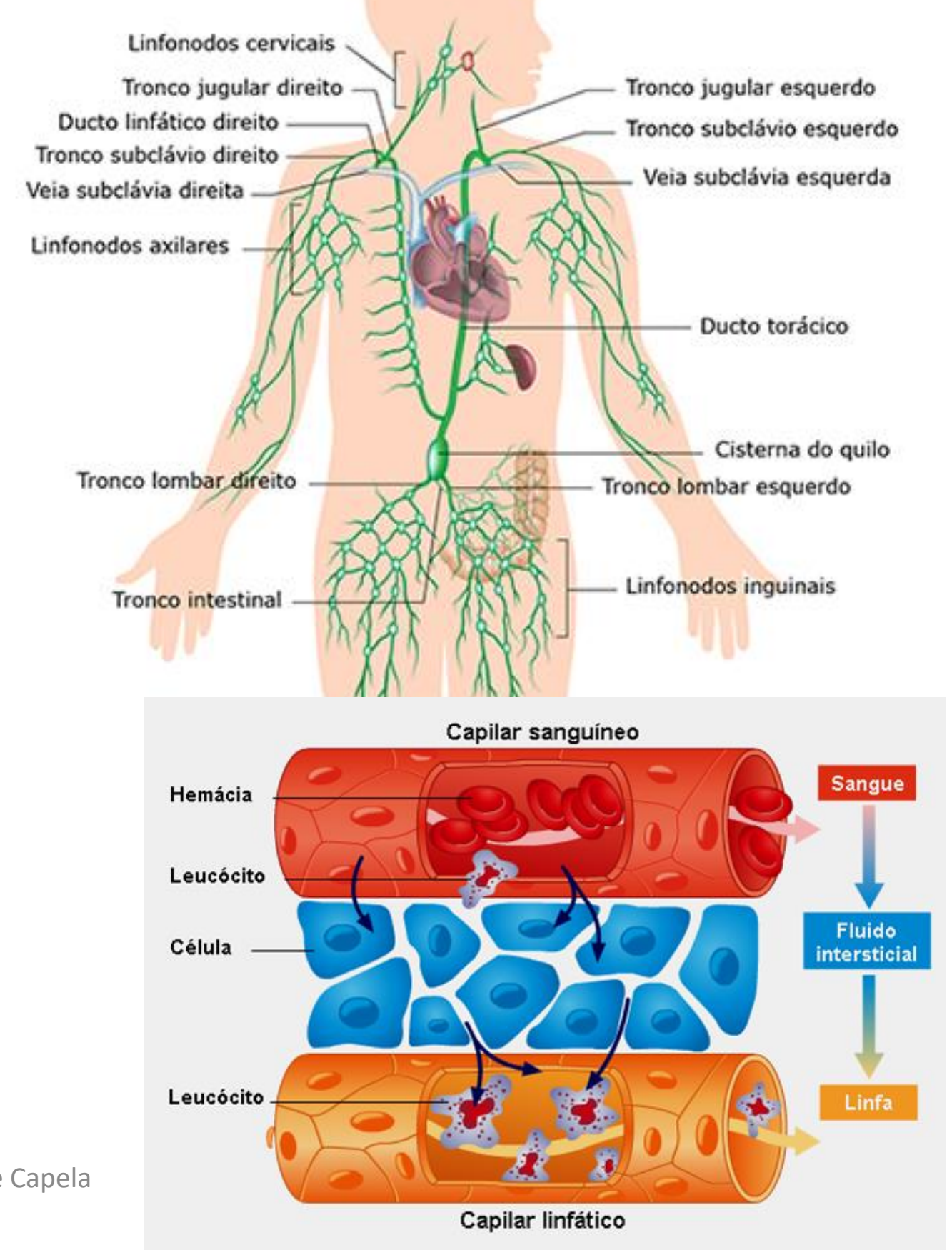




\section{Sistema nervoso}

Responsável pela coordenação, captação, interpretação e respostas às mensagens/estímulos recebidas. Elabora respostas, as quais podem ser dadas na forma de movimentos, sensações ou constatações. Formado pelo Sistema Nervoso Central, envolvido pelas meninges:

- 1. Encéfalo

- 1.1. Cérebro, pensamento, memória, visão, audição, tato, paladar, fala, escrita, movimentos voluntários do corpo.

- 1.2. Cerebelo coordena os movimentos e o equilibrio

- 1.3. Tronco cefálico ligação à espinal medula,

- movimentos respiratórios, os batimentos cardíacos e

- os reflexos, como a tosse, o espirro e a deglutição

- 2. Espinal Medula

E pelo Sistema Nervoso Periférico (nervos sensoriais e motores):

- Nervos cranianos - cabeça e do pescoço

- Nervos raquidianos

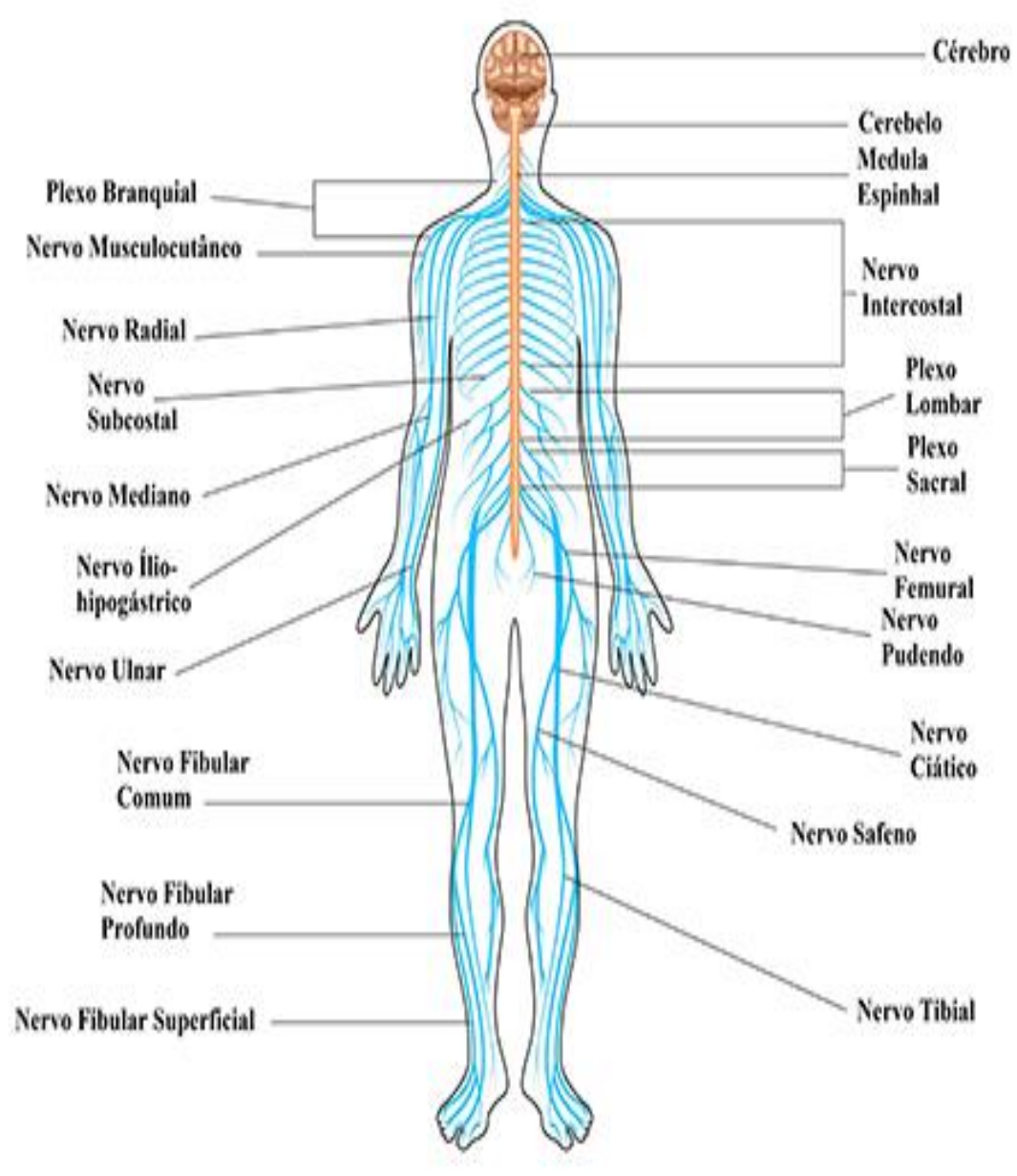




\section{Sistema digestivo}

Responsável pela digestão dos alimentos

Composto pelo tubo digestivo:

- Boca

- Faringe

- Esófago

- Estômago

- Intestino Delgado

- Intestino Grosso

- Ânus

E órgãos anexos:

$>$ Glândulas salivares

$>$ Dentes

$>$ Língua

$>$ Pâncreas

$>$ Fígado e Vesícula Biliar

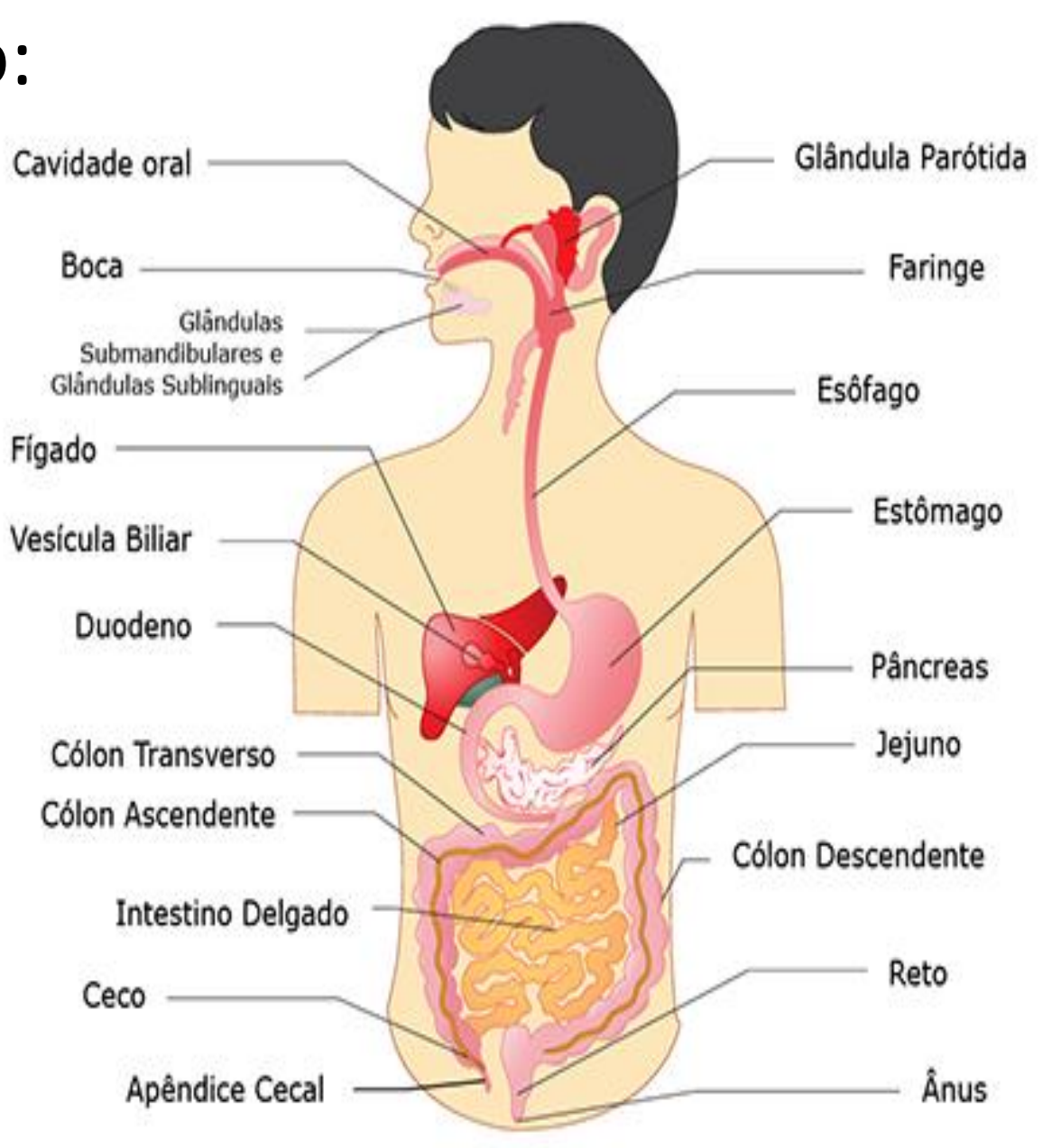




\section{Sistema digestivo}

- Boca: Digestão mecânica (dentes e língua), química (glândulas salivares: amilase salivar - amido) Formação do bolo alimentar.

- Faringe (epiglote)

- Esófago: Peristaltismo

- Estômago (Cárdia, Corpo e Piloro): movimento de mastigação ativa a produção do ácido clorídrico no estômago. E somente com a presença de proteína, que se inicia a produção do suco gástrico (pepsina). Formação do quimo.

- Intestino Delgado (duodeno, jejuno e íleo): Bílis (emulsificação de lípidos, produzida no fígado e armazenada na vesícula biliar), Suco Pancretático (neutralização do PH do quimo), Absorção nas Vilosidades Intestinais.

- Intestino Grosso (Ceco - formação do bolo fecal, cólon e reto): absorção de água (ingerida e secreções digestivas), de armazenamento e de eliminação dos resíduos digestivos.

- Ânus: eliminação fezes 


\section{Sistema endócrino}

Formado por glândulas que produzem hormonas que possuem determinadas funções vitais como: regulação do metabolismo, defesa do organismo, produção de gâmetas, desenvolvimento corporal, etc.

Hipófise - glândula mestre e hormona do crescimento

e anti-diurética

Tiróide - produz a tiroxina, hormona da velocidade do metabolismo celular, na manutenção do peso e do calor corporal e no ritmo cardíaco.

Paratiróides - regulam a quantidade de cálcio e de fósforo no sangue.

Timo - produz hormona que atua na defesa do recém-nascido contra infecções.

Supra-renais - Produção de adrenalina (taquicardia, Aumento glicose sangue, vasoconstrição e hiperventilação) Pâncreas - Insulina (glicose nas células e armazenamento de glicogénio no fígado) e Glucagon Sexuais: Ovários (estrogénio e progesterona) e Testículos (testosterona)
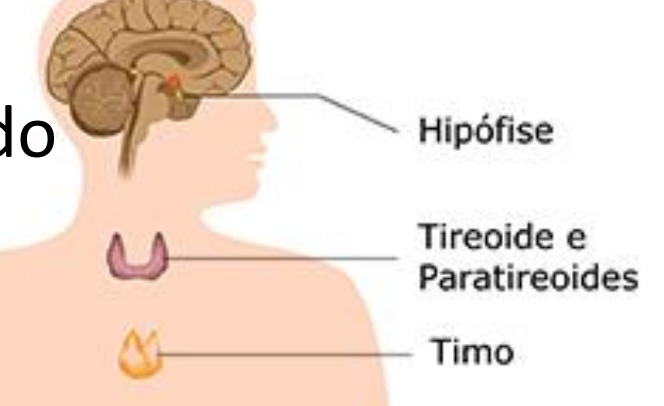
Pâncreas Suprarrenais
Glândulas

sexuais 


\section{Sistema excretor}

Responsável pela eliminação de resíduos provenientes do metabolismo celular, e equilíbrio interno de sais minerais no organismo. Produção, transporte e eliminação de urina.

\section{Metabolitos:}

Glícidos e Lípidos: $\mathrm{CO} 2$ e H2O

Proteínas: $\mathrm{CO} 2, \mathrm{H} 2 \mathrm{O}$, Amónia, Ureia, Ácido Úrico

\section{Órgãos:}

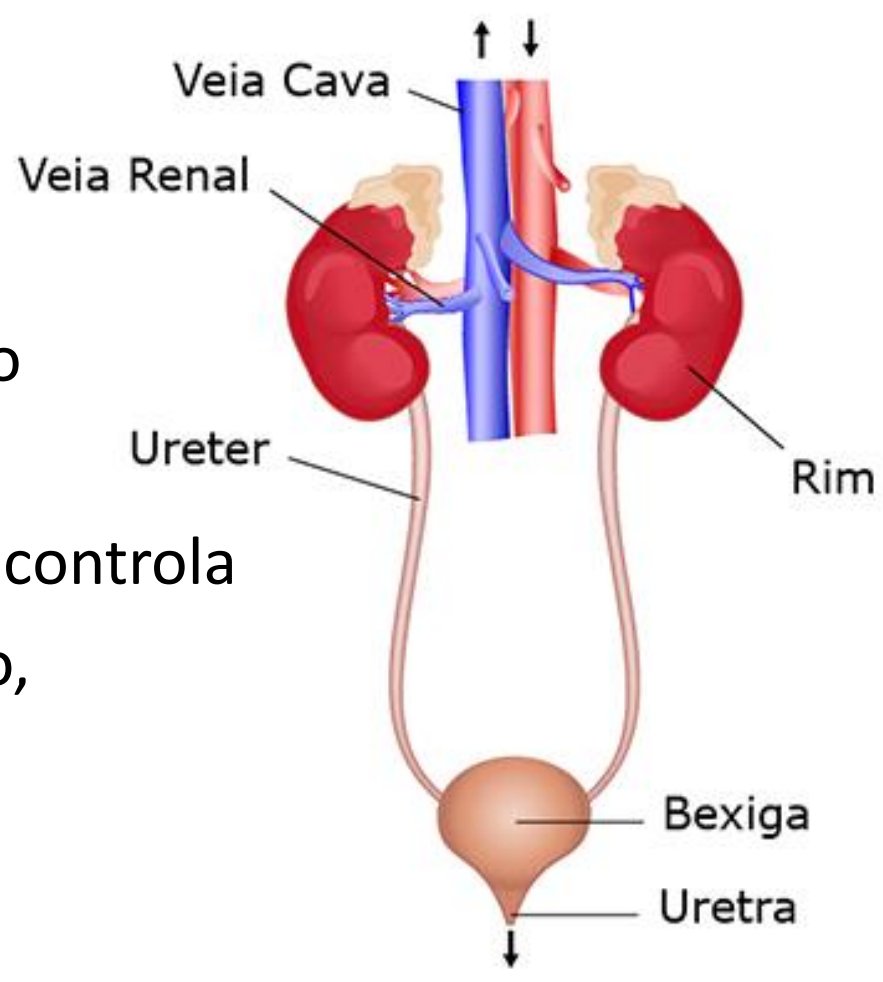




\section{Sistema reprodutor}

Reprodução de novos seres. Masculino: é formado pelos testículos, epidídimo, canais deferentes, vesículas seminais, próstata, uretra e pênis; o sistema reprodutor feminino é composto pelos ovários, útero, trompas de Falópio e vagina.
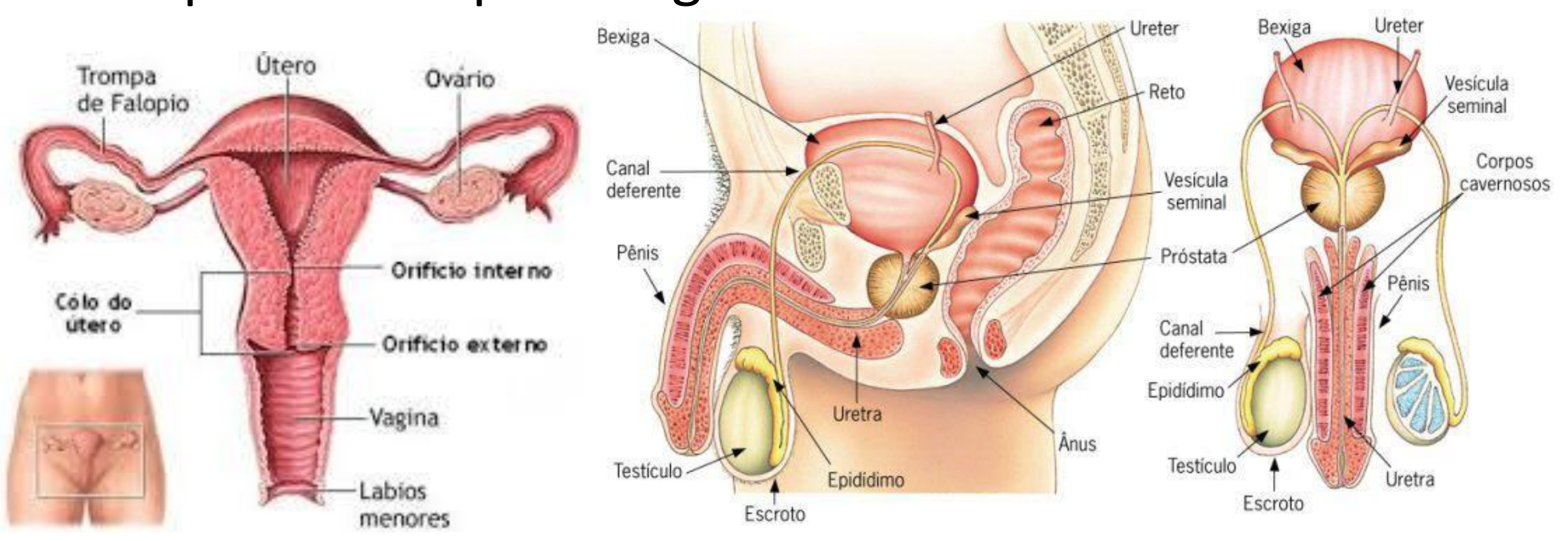


\section{Sistema sensorial}

Formado pelos 5 sentidos do corpo humano:

1. Tato

2. Audição

3. Visão

4. Paladar,

5. Olfato
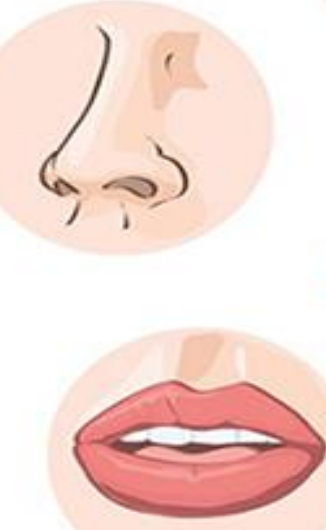

(c)

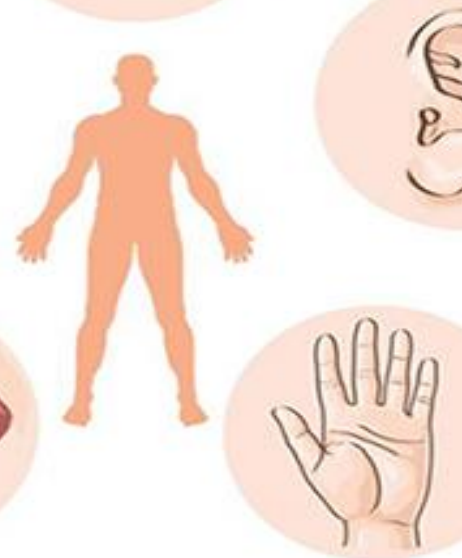

O sistema sensorial está encarregado de enviar as informações recebidas para o sistema nervoso que as decodifica e envia respostas para o corpo. 


\section{Sistema esquelético}

Dá forma e sustenta todo o corpo, protege os órgãos internos e desempenha um papel importante nos movimentos, juntamente com o sistemas muscular e articulações. Outras funções são a produção de células sanguíneas na medula óssea e armazenamento de sais minerais

\section{Ossos}

Cartilagens

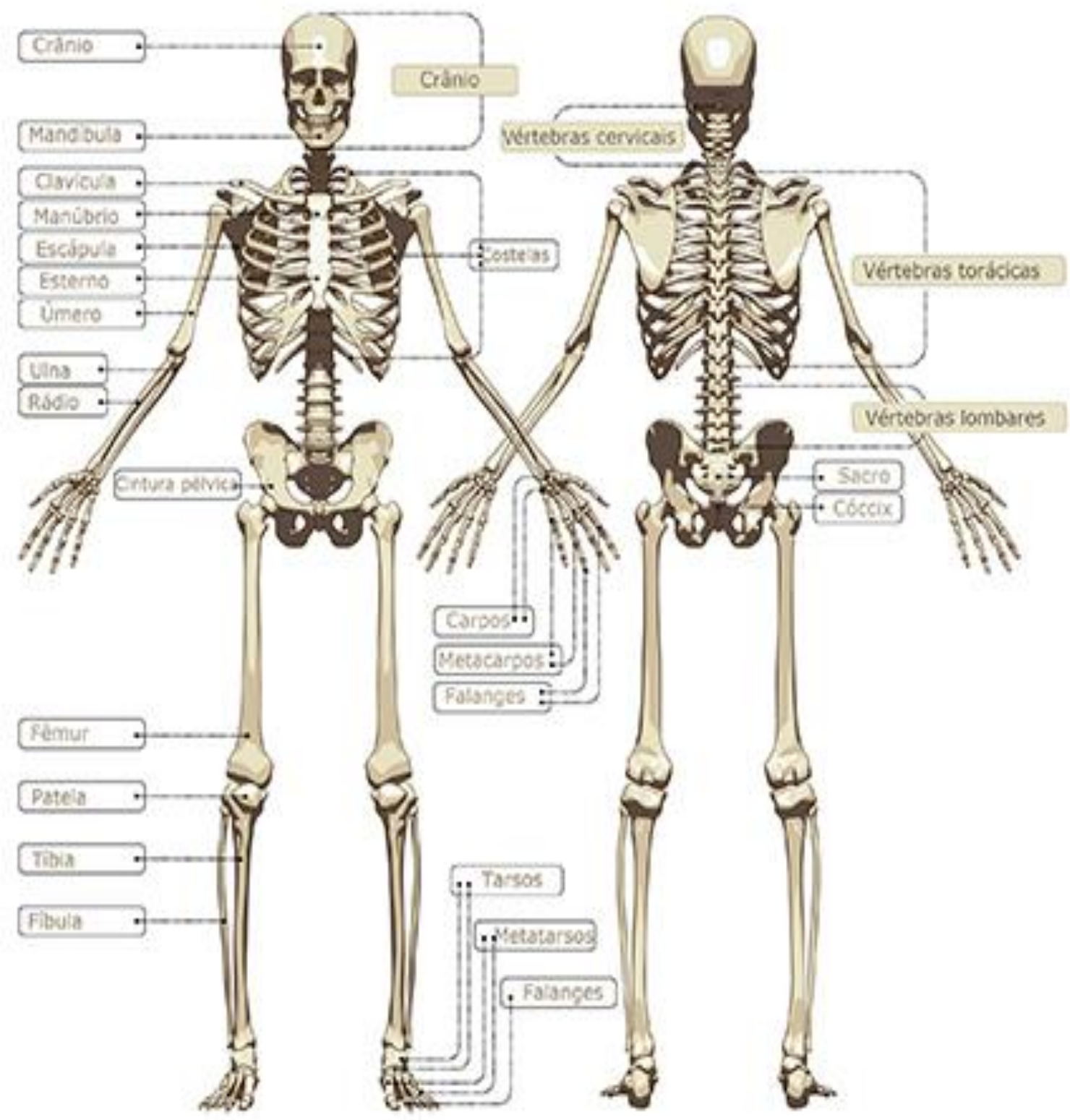


Estabiliza e ajuda a sustentar todo o nosso corpo, contribui na produção dos movimentos, ajuda a regular a temperatura corporal e auxilia o fluxo sanguíneo e da linfa.

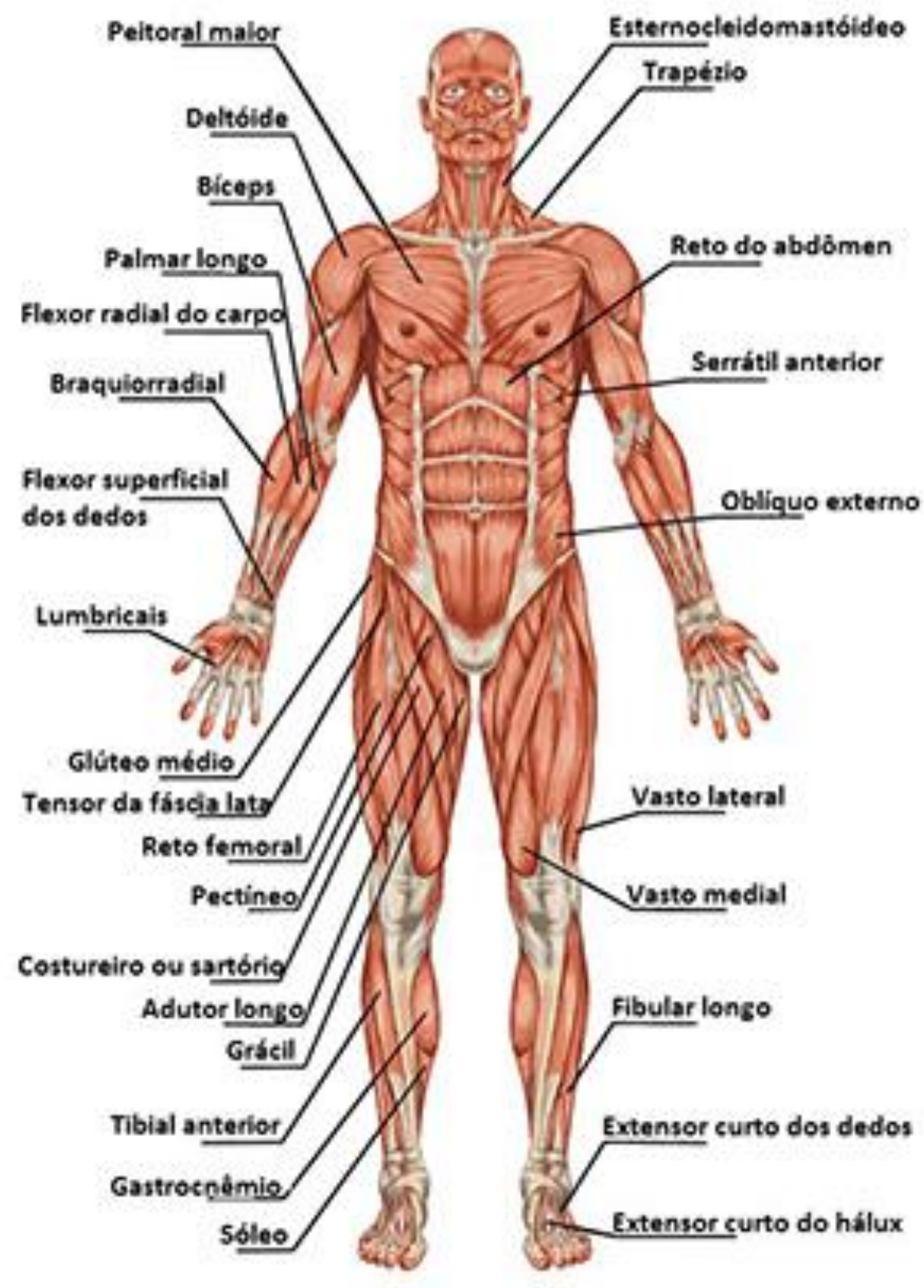




\section{Serviços hospitalares}

- Anatomia patológica (diagnóstico através de análise macro e microscópica de tecidos, órgãos e fluidos corporais)

- Anestesiologia (manutenção homeostasia em contexto peri-operatório, controlo da dor)

- Cardiologia (diagnóstico e tratamento de doenças do coração)

- Cirurgia cardiotoráxica (órgãos da cavidade toráxica)

- Cirurgia geral (doenças do sistema digestivo, doenças endócrinas (supra-renal e tiróide), mama, hérnias da parede abdominal)

- Cirurgia maxilo-facial (patologia oncológica cervico-facial, articulação temporomandibular, face e cavidade oral)

- Cirurgia plástica, reconstrutiva e estética (malformações pele)

- Cirurgia vascular (artérias, veias e vasos linfáticos)

- Cuidados continuados / paliativos (doentes com perda de autonomia e necessidade de reabilitação/ doenças incuráveis e progressivas)

- Dermatologia (doenças da pele, mucosas e sexualmente transmissíveis) 


\section{Serviços hospitalares}

- Endocrinologia (perturbações sistema endócrino)

- Estomatologia (concorrente medicina dentária)

- Gastroenterologia (sistema digestivo)

- Genética médica (doenças de origem genética)

- Ginecologia (doenças do aparelho reprodutor feminino) e obstetrícia (gestação, parto e pós-parto)

- Hematologia (doenças do sangue e órgãos que intervêm na sua formação)

- Imagiologia (diagnóstico através do uso de imagens por radiação ionizante (RX, TAC, mamografia), ultrassons (ecografia) ou radio-frequência (RM))

- Imunoalergologia (doenças do sistema imunitário)

- Imunohematologia (tratamento com sangue e derivados)

- Medicina dentária (doenças dos dentes e estruturas de suporte)

- Medicina desportiva (doenças da prática desportiva)

- Medicina física e de reabilitação (deficiências e incapacidades funcionais)

- Medicina geral e familiar (seguimento longo prazo) 


\section{Serviços hospitalares}

- Medicina interna (órgãos e sistemas ou afeções multisistémicas de adolescentes, adultos e idosos em casos de doença aguda)

- Medicina molecular (avaliação da doença a nível modelular pela utilização de núcleos radioativos - medicina nuclear)

- Nefrologia (rins)

- Neonatologia (doenças dos recém-nascidos e prematuros)

- Neurocirurgia (tratamento cirúrgico das doenças do SNC e periférico e da patologia da coluna vertebral)

- Neurologia (sistema nervoso)

- Neuroradiologia (diagnóstico imagem em patologias do encéfalo, medula, órgãos sensoriais, sistema nervoso periférico, coluna vertebral, cabeça e pescoço)

- Nutrição (necessidades nutricionais e planeamento alimentar)

- Oftalmologia (doenças olhos)

- Oncologia (cancro)

- Ortopedia (doenças sistema locomotor) 


\section{Serviços hospitalares}

- Otorrinolaringologia (doenças dos ouvidos, nariz, garganta, cabeça, pescoço, incluindo glândulas salivares e voz).

- Patologia clínica (diagnóstico laboratorial)

- Pediatria (saúde física, emocional e social das crianças e jovens)

- Pneumologia (doenças do sistema respiratório)

- Podologia (doenças do pé)

- Psicologia (avaliação e análise de aspetos comportamentais)

- Psiquiatria (problemas mentais, emocionais ou comportamentais)

- Radiologia (tratamento de doenças benignas e cancro pela radiação)

- Reumatologia (doenças reumáticas: Osteoartrose; Raquialgias (dores na coluna vertebral); lesões musculoesqueléticas; Osteoporose; Fibromialgia; Artropatias microcristalinas; Artrite Reumatóide)

- Urologia (tratamento médico e cirúrgico das doenças do aparelho urinário e genital masculino) 


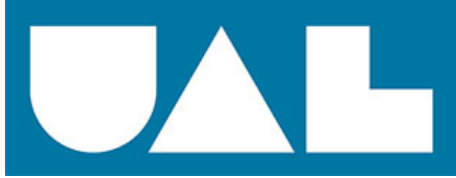

\title{
Saúde Clínica e Saúde Pública
}

$3^{\underline{a}}$ sessão:

Saúde Pública, Áreas de Intervenção e Recursos

\author{
Denise Capela dos Santos
}

Lisboa, 2018 


\section{Sumário}

Saúde clínica vs saúde pública

Conceito de saúde pública

Questões fundamentais em saúde pública

Áreas de intervenção

Recursos

Reforma da Saúde Pública em Portugal 2017/2018

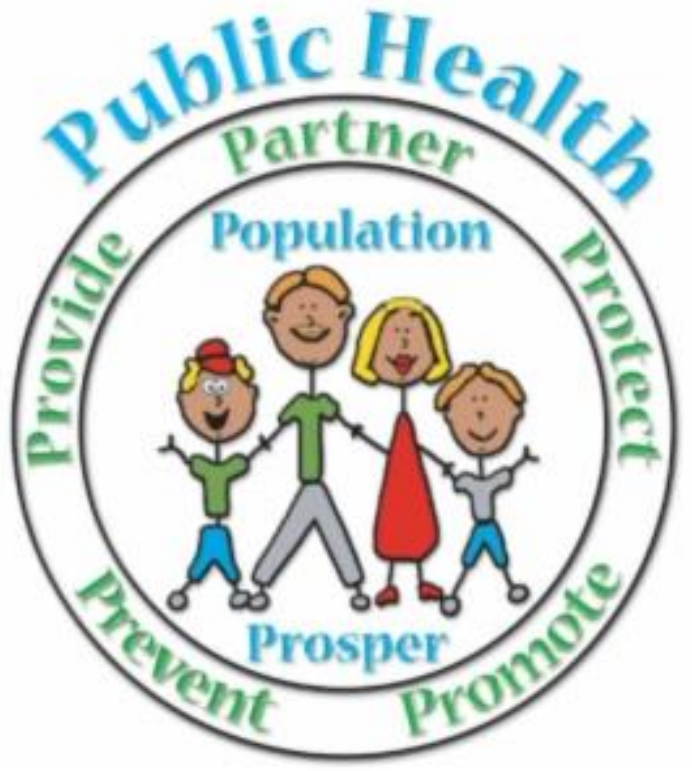




\section{Saúde Clínica vs Saúde Pública}

\begin{tabular}{|l|l|l|}
\hline Indicadores & Saúde Clínica & Saúde Pública \\
\hline Objeto de investigação & $\begin{array}{l}\text { Doente com doença a } \\
\text { diagnosticar }\end{array}$ & $\begin{array}{l}\text { Comunidade onde se } \\
\text { procuram conhecer as causas } \\
\text { que determinam o } \\
\text { aparecimento da doença e a } \\
\text { sua evolução }\end{array}$ \\
\hline Intervenção & $\begin{array}{l}\text { Direta, por via } \\
\text { farmacológica, cirúrgica } \\
\text { ou outra visando a cura }\end{array}$ & $\begin{array}{l}\text { Indireta, recorrendo a } \\
\text { medidas não clínicas visando } \\
\text { controlar ou erradicar a } \\
\text { doença }\end{array}$ \\
\hline Sucesso da intervenção & $\begin{array}{l}\text { Avaliado por diagnóstico } \\
\text { da melhoria do estado } \\
\text { de saúde do indivíduo }\end{array}$ & $\begin{array}{l}\text { Avaliado por indicadores } \\
\text { sanitários que traduzem o seu } \\
\text { impacto na comunidade }\end{array}$ \\
\hline
\end{tabular}




\section{Conceito de saúde pública}

"Ação coletiva para a melhoria sustentada da saúde da população, em larga escala."

Beaghole (2004)

Exige o esforço de cada um, e de todos, em conjunto, em função das suas competências e potencialidades, e o apoio de políticas que garantam infraestruturas e oportunidades para uma melhor qualidade de vida.
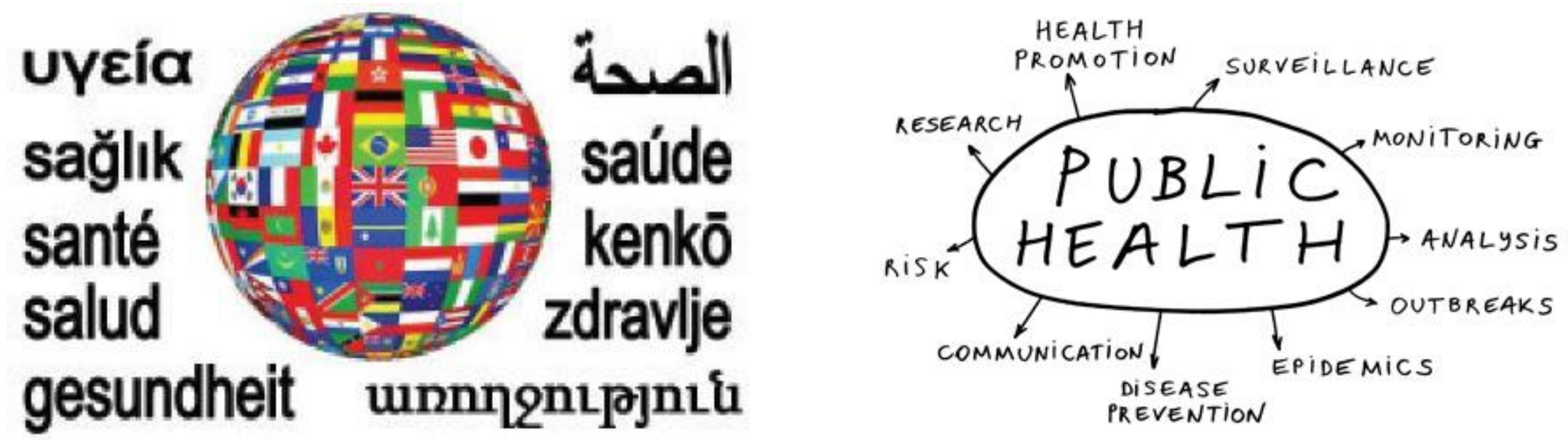


\section{Conceito de saúde pública}

"Processo de mobilização e organização a nível local, regional, nacional e internacional dos recursos necessários para garantir o maior potencial de saúde ao maior número de pessoas."

Cabrita, José (2014)

\section{Pressupõe:}

Conhecimento das causas e mecanismos que condicionam o aparecimento e evolução das doenças na comunidade Definição dos objetivos a atingir na luta contra a doença e promoção da saúde

A escolha adequada das estratégias e meios para atingir os objetivos propostos.

Existência de 4 fatores:

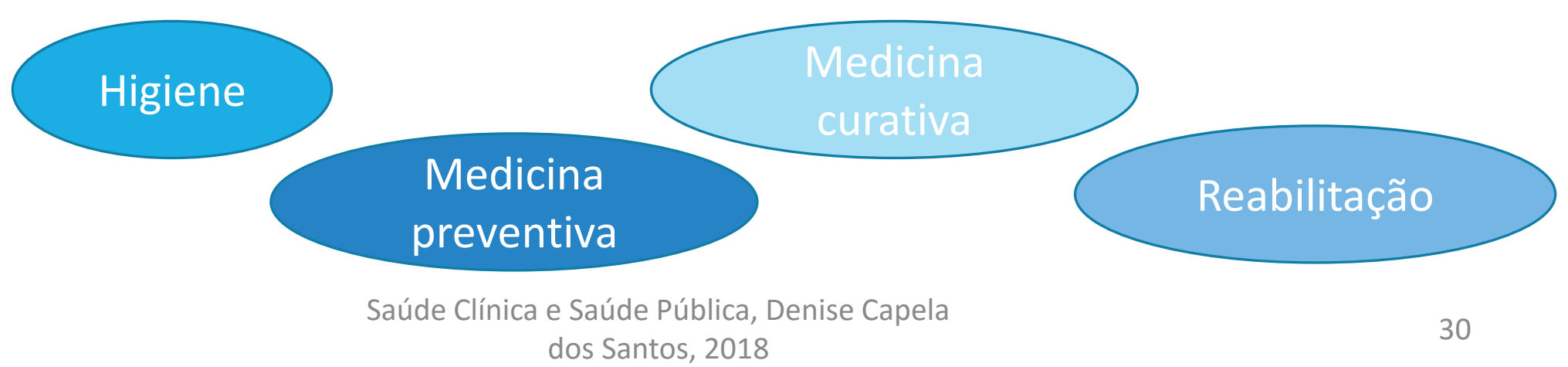




\section{Questões fundamentais em saúde}

pública

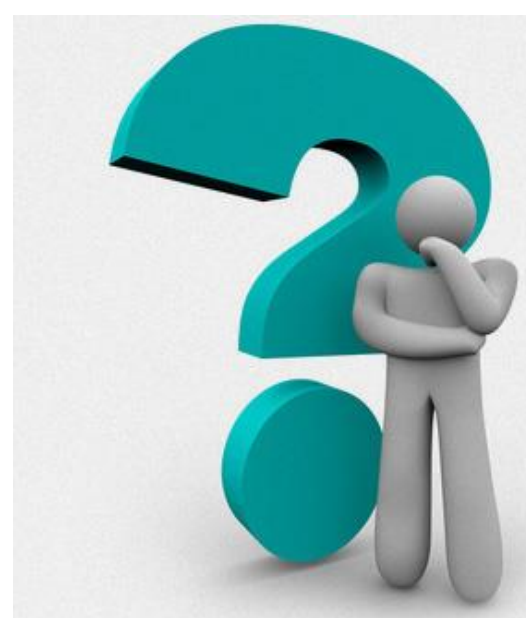

- Qual a finalidade em promover a saúde?

- Como ter ganhos em saúde?

- Como definir as prioridades em saúde?

- Como assegurar a participação da comunidade?

- Como garantir a eficiência e a cooperação? 


\section{Fatores que modelam a saúde}

- Circunstâncias sociais e políticas e respetivos interesses

$\square$ Situação demográfica

$\square$ Condições ambientais

$\square$ Sistema(s) de valores dominantes

$\square$ Recursos disponíveis

$\square$ Tecnologia existente

$\square$ Perceção das necessidades 


\section{Dificuldades atuais}

$>$ Evolução desfavorável de alguns indicadores

$>$ Aumento desmesurado da despesa

$>$ Novas causas de morbi-mortalidade emergentes

$>$ Agravamento das desigualdades

$>$ Insatisfação de profissionais e de utentes

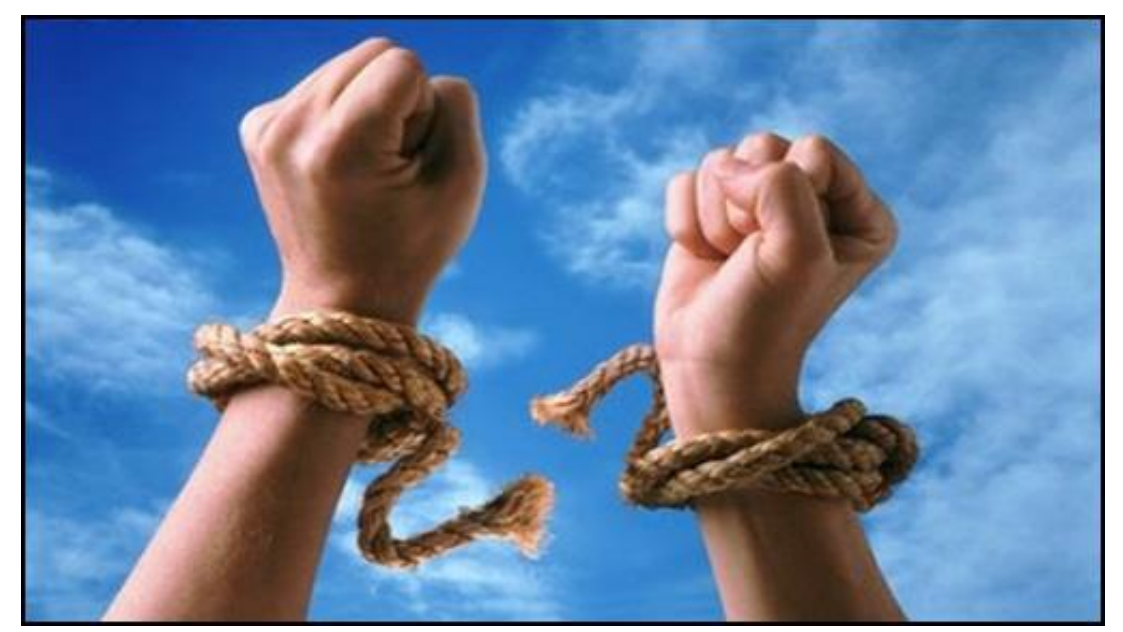




\section{Áreas de intervenção em saúde Pública}

1. Medição e Indicadores de saúde;

2. Monitorização do estado de saúde;

3. Planeamento estratégico em saúde;

4. Avaliação de impacto em saúde;

5. Vigilância epidemiológica;

6. Análise e gestão do risco;

7. Gestão de programas e projetos de promoção e proteção da saúde;

8. Investigação em saúde pública. 


\section{Áreas de Intervenção em Saúde}

\section{Pública}

\section{Medição e indicadores em saúde}

\section{A. Indicadores de Recursos e Atividades em Saúde}

Gastos com a saúde (despesa pública, privada e despesa total per capita

e \% do PIB, despesa com medicamentos)

N.. o de médicos por 100.000 habitantes

N.ㅇ de enfermeiros por 100.000 habitantes

N. de farmacêuticos por 100.000 habitantes

N. ㅇ de habitantes por cama hospitalar

N.o de consultas médicas por hab. por ano por região

$\%$ de população vacinada com BCG, Rubéola e Hepatite

$\%$ de partos com assistência 


\section{Áreas de Intervenção em Saúde}

\section{Pública}

1. Medição e indicadores em saúde

B. Indicadores Sócio-Económicos

PIB per capita

\% da População ativa por setor de atividade

$\%$ de População por nível de escolaridade

$\%$ da População que reside em áreas urbanas

Taxa de desemprego por região de residência

Salário mínimo

Taxa de inflação anual 


\section{Áreas de Intervenção em Saúde}

\section{Medição e indicadores em saúde}

- Indicadores de Salubridade Ambiental

$\%$ de alojamentos com água potável

$\%$ de alojamentos com instalações sanitárias

$\%$ de população servida por redes de esgotos

Concentração de poluentes no ar, água e solo

- Indicadores de Consumo de Alimentos e de Nutrição

Consumo energético por dia per capita (Kcal)

Distribuição do consumo energético por nutrientes

Consumo de leite por dia per capita

Consumo de álcool por dia per capita

Consumo anual de pescado e carne/ ovos/ cereais, legumes e frutos/

lacticínios, per capita

Consumo anual de gordura/ açúcar/ álcool/ café, per capita

$\%$ indivíduos com IMC superior a 27, por faixa etária. 


\section{Áreas de Intervenção em Saúde}

\section{Pública}

\section{Monitorização do estado de saúde}

A monitorização é utilizada para avaliar em que medida as metas planeadas estão a ser atempadamente atingidas. A monitorização ajuda os gestores dos programas e projetos a determinar, com regularidade, que áreas exigem mais esforço de intervenção e a identificar aquelas que poderão contribuir para atingir uma resposta mais adequada. É muito importante selecionar um conjunto limitado de indicadores, do nível local para o regional.

ARS Norte: Programas:

\section{M\&A - Monitorização e Avaliação mort@lidades morbilid@des Carga Global da Doença Desigualdades em Saúde}




\section{Áreas de Intervenção em Saúde}

\section{Pública}

\section{Monitorização do estado de saúde}

Quadro 1: Frequências sugeridas para a recolha de informação

\begin{tabular}{|c|c|l|}
\hline Nível do indicador & $\begin{array}{c}\text { Frequência recomendada para } \\
\text { a recolha de dados }\end{array}$ & $\begin{array}{c}\text { Exemplos de métodos de } \\
\text { recolha de dados }\end{array}$ \\
\hline $\begin{array}{c}\text { Estrutura/ processo } \\
\text { (Inputs) }\end{array}$ & Contínuo & $\begin{array}{l}\text { - Estatística dos serviços saúde } \\
\text { - Inquéritos em serviços saúde } \\
\text { - Programa de monitorização }\end{array}$ \\
\hline $\begin{array}{c}\text { Resultados Directos } \\
\text { (Outputs) }\end{array}$ & Trimestral, semestral ou anual & $\begin{array}{l}\text { - Estatística dos serviços saúde } \\
\text { - Inquéritos em serviços saúde } \\
\text { - Programa de monitorização }\end{array}$ \\
\hline $\begin{array}{c}\text { Resultados Indirectos } \\
\text { (Outcomes) }\end{array}$ & De 1 a 3 anos & $\begin{array}{l}\text { - Inquéritos populacionais } \\
\text { Inquéritos em serviços saúde }\end{array}$ \\
\hline Impacto & Dstudos especiais \\
\hline & $\begin{array}{l}\text { De } 2 \text { a } 5 \text { anosilância } \\
\text { - Inquéritos populacionais } \\
\text { - Estudos especiais }\end{array}$ \\
\hline
\end{tabular}




\section{Áreas de Intervenção em Saúde}

\section{Pública}

3. Planeamento estratégico em saúde

O Planeamento em Saúde consiste na "... racionalização na utilização de recursos escassos com vista a atingir os objectivos fixados, em ordem à redução dos problemas de saúde considerados como prioritários, e implicando a coordenação de esforços provenientes dos vários sectores sócio económicos...".

(Imperatori e Giraldes, 1982) 


\section{Áreas de Intervenção em Saúde}

\section{Pública}

\section{Planeamento estratégico em saúde}

E porquê planear?

$\square$ Porque os recursos são cada vez mais escassos e é necessário utilizá-los da maneira mais eficaz e mais eficiente;

$\square$ Porque é necessário intervir nas causas dos problemas;

$\square$ Porque é necessário basear cada vez mais as decisões de intervenção e as diversas intervenções projetadas, na evidência que, a cada momento, for possível recolher;

$\square$ Porque é necessário ter instrumentos que permitam definir, de um modo dinâmico, quais as principais prioridades de intervenção;

$\square$ Porque é necessário evitar intervenções isoladas e implementar abordagens integradas que utilizem e potenciem as sinergias existentes;

$\square$ Porque é necessário utilizar e adequar os Serviços e os seus recursos de modo a poderem responder, atempada e adequadamente, aos principais problemas e necessidades de saúde que forem identificados. 


\section{Áreas de Intervenção em Saúde Pública}

3. Planeamento estratégico em saúde

\section{Ex: ARS NORTE}

Queremos aproximar a informação sobre a saúde e os seus determinantes, da tomada de decisão pessoal, política e institucional sobre saúde, na região!

Medir para Mudar 2005

Perfis de Saúde

PRSN 2014-2016

PRSN 2009-2010

Planos e Relatórios 


\section{Áreas de Intervenção em Saúde}

\section{Pública}

\section{Avaliação de impacto em saúde}

\section{Ex: ARS NORTE :Estudo "Mortalidade Evitável: uma análise evolutiva na região Norte de Portugal"}

A análise das mortes evitáveis em diferentes populações permite, entre outros, estudar

a efetividade das intervenções dos serviços de saúde e o seu impacto na saúde das populações.

"Espera-se que esta análise (regional e ao nível das NUTS III) da evolução da mortalidade evitável na região Norte, nos quinquénios 1989-1993, 1994-1998 e 2001-2005, possa ajudar-nos a refletir sobre a sua evolução no passado, para podermos perspetivar, adequar e melhorar a efetividade da intervenção dos serviços de saúde na região (quer na prestação direta de cuidados de saúde, quer na prevenção da doença e promoção da saúde), num momento particularmente exigente para o sistema de saúde e restantes sectores da sociedade." 


\section{Áreas de Intervenção em Saúde}

\section{Pública}

\section{Vigilância Epidemiológica}

A vigilância epidemiológica dos fenómenos de saúde e dos seus determinantes, na região de saúde do Norte.

As doenças infeciosas têm vindo a reassumir relevância crescente a nível mundial, impondo a identificação de surtos, monitorização da sua evolução e ainda a avaliação de resultados dos programas de vacinação.

Programas ARS Norte:

DDO- Doenças de declaração obrigatória

Absentismo escolar

Doença dos legionários

SARA - Meningites 


\section{Áreas de Intervenção em Saúde Pública}

\section{Vigilância Epidemiológica}

Vacinação ARS Norte:

Relatórios de vacinação contra a gripe sazonal 2013/2014 e 2014/2015 Relatório de avaliação da cobertura - Vacina pneumocócica conjugada 


\section{Áreas de Intervenção em Saúde}

\section{Pública}

\section{Análise e Gestão do Risco}

"A Análise de Risco é uma ferramenta para a tomada de decisões por parte dos operadores com responsabilidades na gestão da saúde pública. Realizando a análise de dados de uma forma estruturada, sistematizada e cientificamente fundamentada, permite a obtenção de indicadores que ajudam na definição de prioridades de atuação e de envolvimento de esforços no que respeita à segurança dos consumidores." (OMS, 2013)

Objetivos:

- a avaliação do potencial de efeitos adversos na saúde como consequência da exposição a um determinado perigo;

- a definição de medidas de mitigação do risco;

- a facilitação da comunicação entre as partes interessadas e envolvidas nos processos de decisão. 


\section{Áreas de Intervenção em Saúde}

\section{Pública}

\section{Análise e Gestão do Risco}

A Análise de Risco contempla três componentes:

1. Avaliação do risco;

2. Gestão do risco;

3. Comunicação do risco.

1. A Avaliação do risco engloba a avaliação científica de efeitos adversos reais ou potenciais, resultantes da exposição a um determinado perigo.

a) que efeitos um determinado perigo pode provocar?

(identificar e caracterizar o perigo)

b) qual a probabilidade de ocorrência?

(avaliar a exposição a que os consumidores estarão sujeitos)

c) se ocorrer quais são as consequências?

(caracterização do risco e recomendações de suporte às decisões a tomar na Gestão do risco) 


\section{Áreas de Intervenção em Saúde}

\section{Pública}

\section{Análise e Gestão do Risco}

2. A Gestão do risco é um processo político e administrativo onde se define o risco "aceitável" baseado em considerações éticas, económicas, práticas e científicas para definição, implementação e revisão das medidas de controlo consideradas adequadas.

3. A Comunicação do risco é um processo interativo, onde existe um intercâmbio de informação e opiniões relacionadas com a avaliação e a gestão do risco. Esta comunicação deverá conter informações corretas e deverá ser formalizada à audiência adequada. 


\section{Áreas de Intervenção em Saúde}

\section{Pública}

7. Gestão de programas e projetos de promoção e proteção da saúde

\section{ARS Norte}

PASSE - Programa Alimentação Saudável em Saúde Escolar COSI - Childhood Obesity Surveillance Initiative MVAA - Máquinas de Venda Automática de Alimentos

Cantinas Escolares - Estudo da Composição dos Alimentos Auto-Estima

HIV-SIDA

Tabaco

Educação para a saúde 


\section{Áreas de Intervenção em Saúde}

\section{Pública}

\section{Investigação em Saúde Pública}

"O benefício último da investigação reside não só na geração de novo conhecimento, como também na tradução do conhecimento em estratégias, tecnologias e intervenções que são efetiva e adequadamente administradas para beneficiar as pessoas, em particular, as mais pobres e outros grupos mais vulneráveis." (Organização Mundial da Saúde, 2005)

Redes para Apoiar a Tomada de Decisão em Saúde e a Formulação da Política de Saúde (Networks to Support Health Decision-Making and Health Policy Formulation). 


\section{Recursos Saúde Pública em Portugal}

Organização de Cooperação e Desenvolvimento

Perfil de saúde Portugal 2017 Políticas de Saúde OMS - Europa
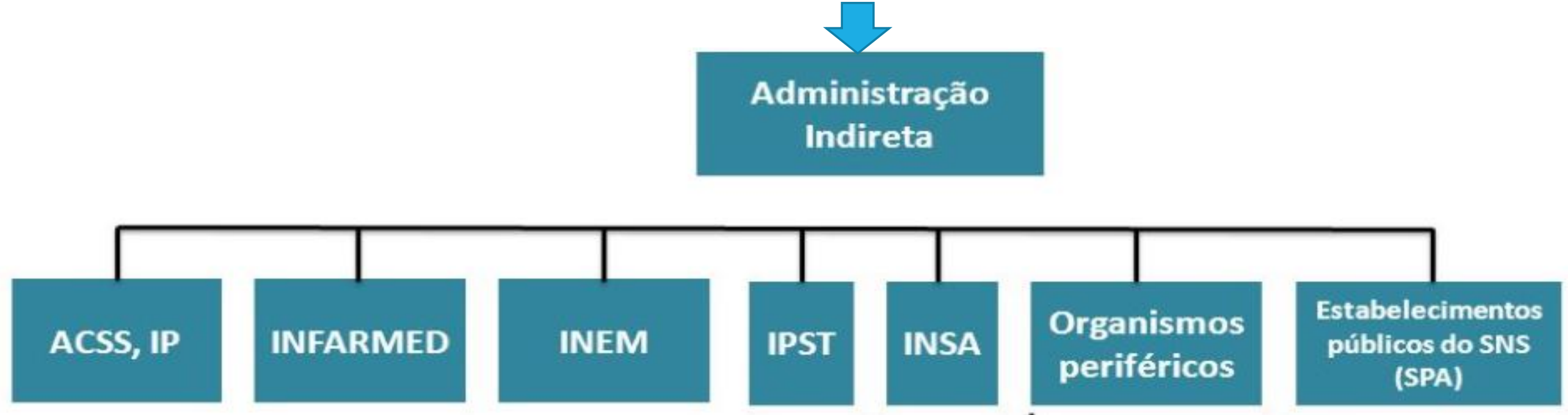

ARS NORTE, IP

ARS CENTRO, IP

ARS LVT, IP

ARS ALENTEIO, IP

Saúde Clínica e Saúde Pública, Denise Capela

ARS ALGARVE, IP 


\section{Saúde}

Pública

a nível

nacional

INSA
Conselho Diretivo

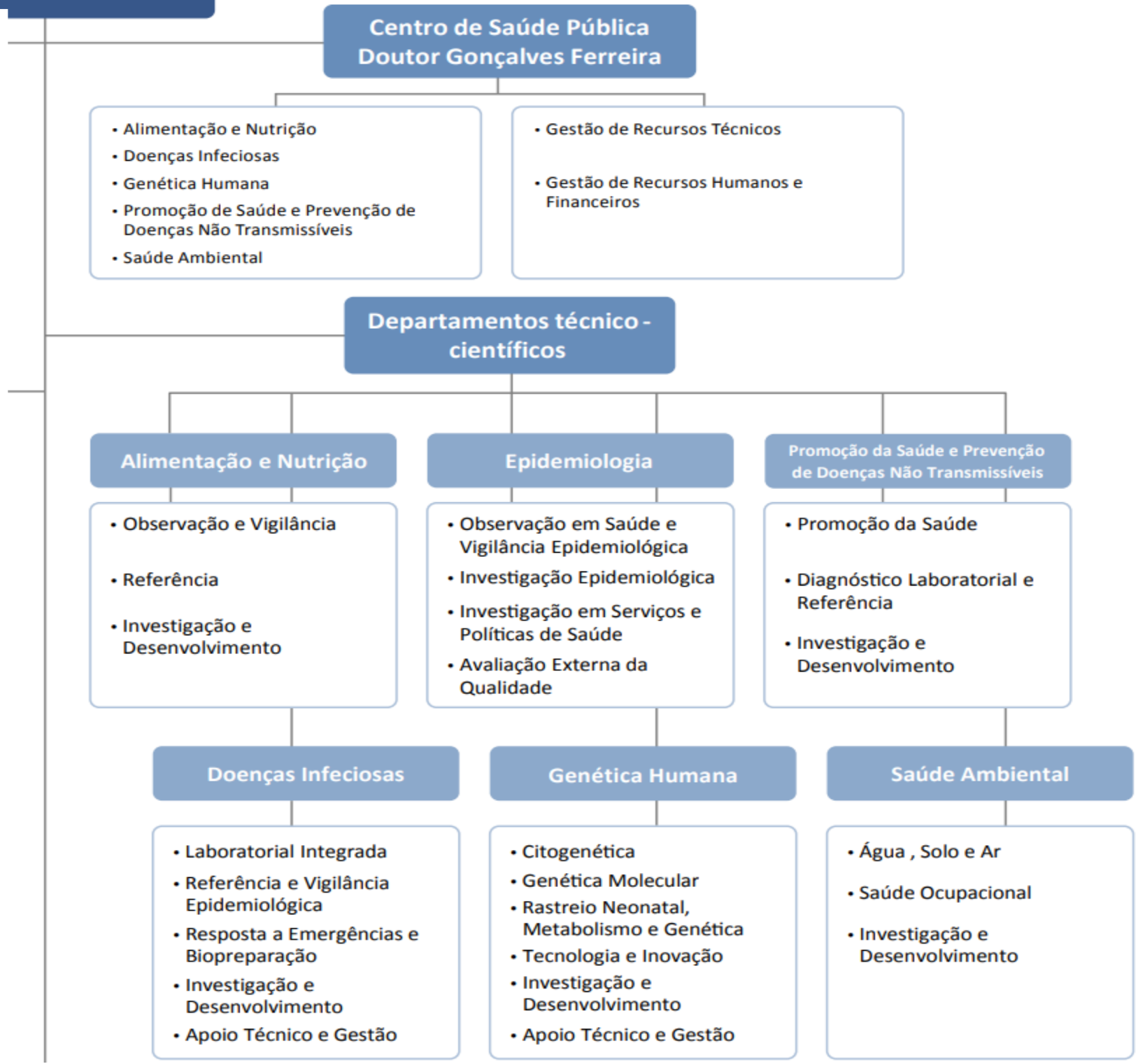




\section{Recursos Saúde Pública em Portugal}

Perfil de regional de saúde 2017

\section{ARS}

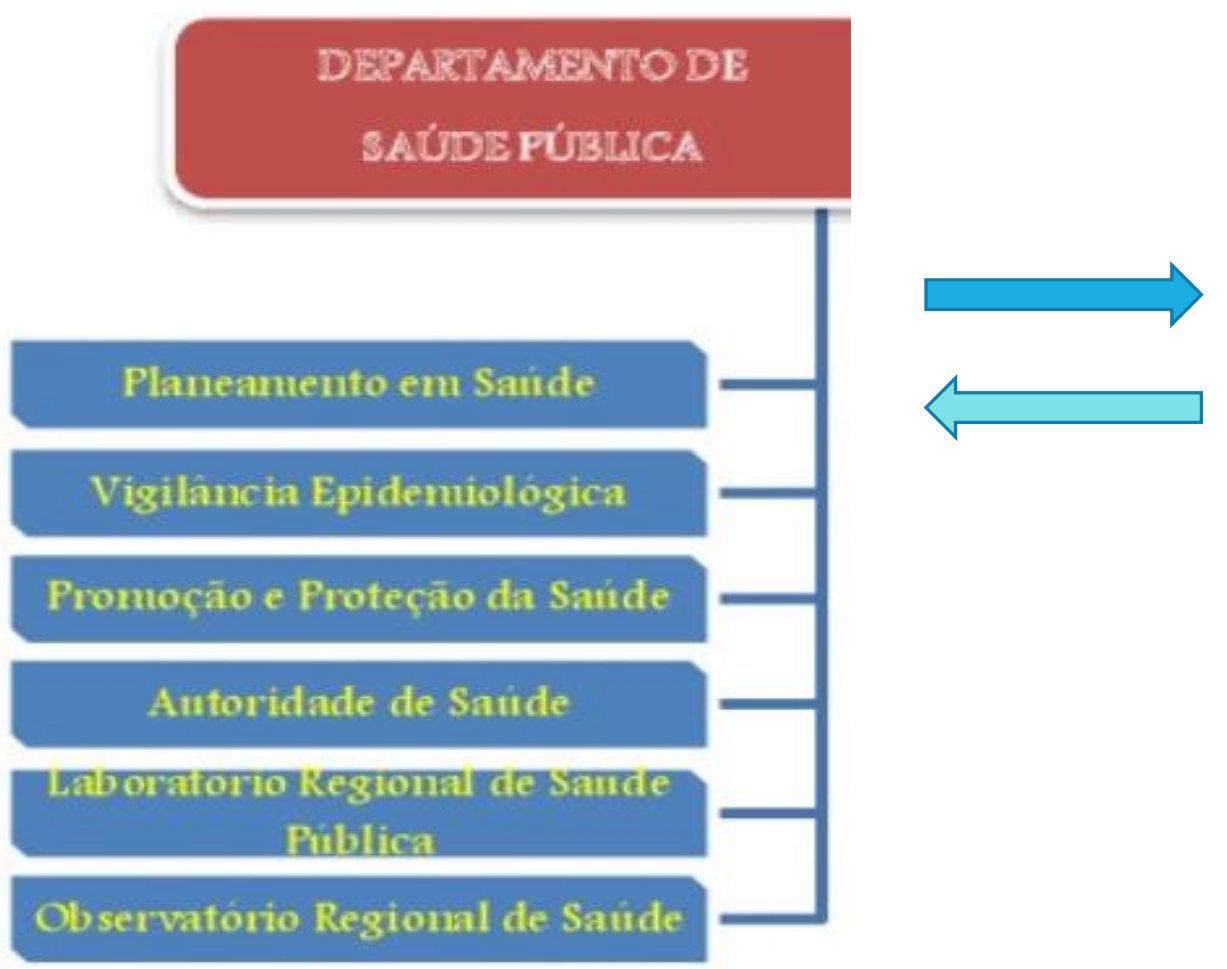

ACES

Unidades de Saúde Pública (USP)

Perfil local de saúde 2018 


\section{REFORMA}

\section{Saúde Pública em Portugal}

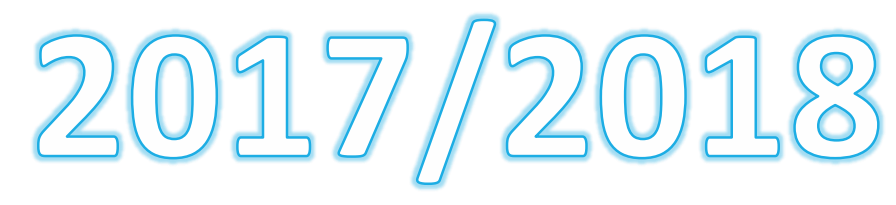

- Capacitação dos Serviços de Saúde Pública

- Modelo de Implementação dos Estudos de Impacte na

Saúde em Portugal

- Modelo de uma Rede de Serviços de Saúde Pública

- Contratualização dos Serviços de Saúde Pública Locais 


\title{
Saúde Clínica e Saúde Pública
}

\author{
$4^{\underline{a}}$ sessão: \\ Saúde, doença e Causalidade
}

Denise Capela dos Santos

Lisboa, 2018 


\section{Sumário}

\section{O conceito de saúde Teorias da causalidade da doença Causalidade e Correlações Ensaios Clínicos}

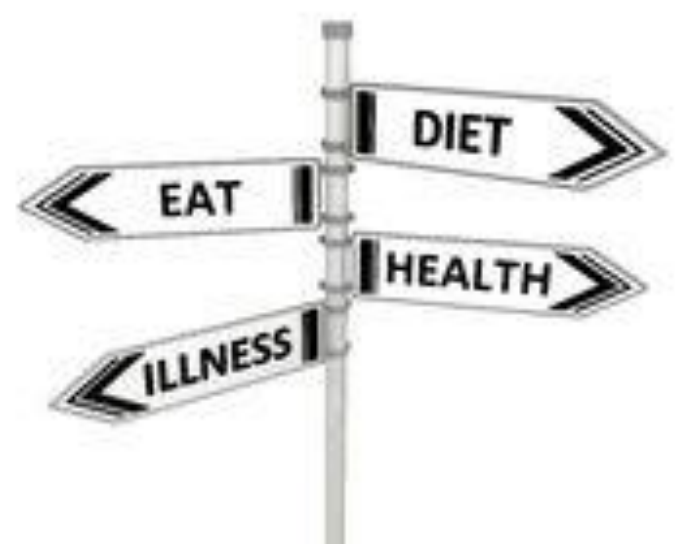




\section{Saúde e doença, conceitos e perspetivas}

Diferentes abordagens do conceito de Saúde (Goldberg)

- Uma perceção de bem estar. (Abordagem Percetual)

- Um estado de capacidade de bem funcionar de forma a cumprir eficazmente as funções e actividades que Ihe são socialmente propostas ou impostas.

(Abordagem Funcional)

- Um estado de adaptação entre a fisiologia do Homem e o Ambiente Físico, Biológico e Social que o envolve. (Abordagem Ecológica) 


\section{Saúde e doença, conceitos e perspetivas}

\section{Saúde: OMS}

Abordagem Perceptual

A Saúde é um estado de completo bem estar físico, mental e social e não apenas a ausência de enfermidade.

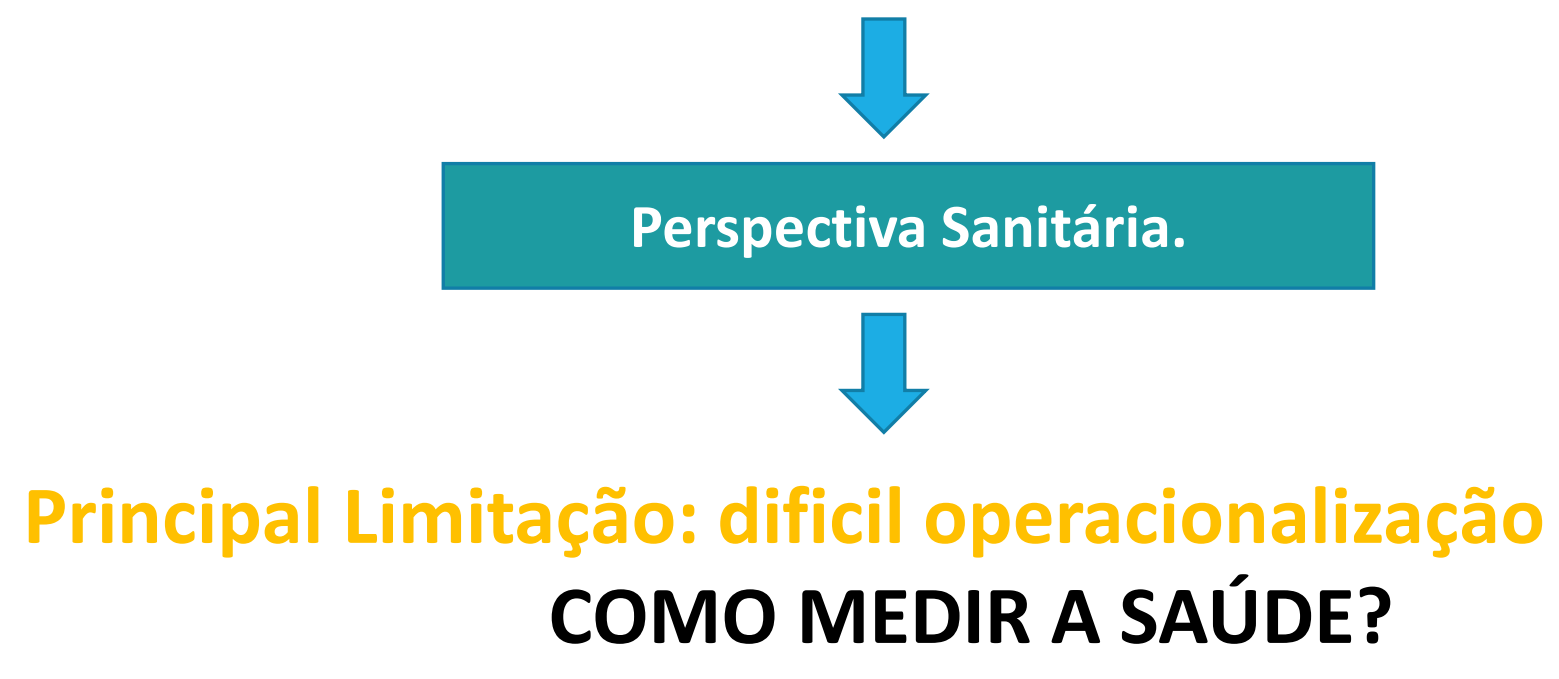




\section{Saúde e doença, conceitos e perspetivas}

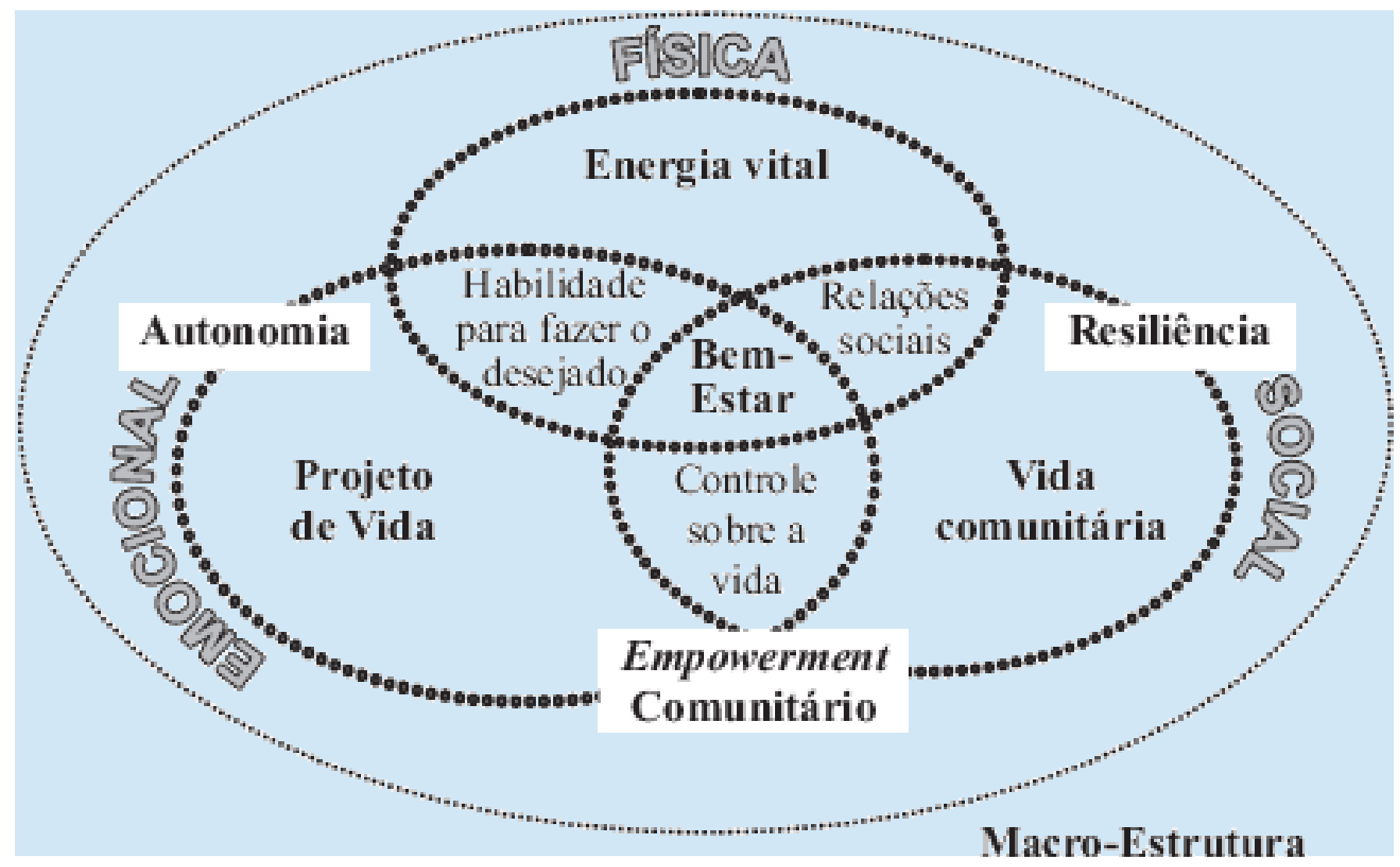




\section{Teorias sobre a causalidade da saúde e da doença}

- Porque é que algumas pessoas têm um estado satisfatório de saúde e outras adoecem?

- Porque razão a mesma doença evolui nalgumas pessoas para a cura e noutras para estados mais graves ou para a morte?

O QUE CAUSA A DOENÇA??? 


\section{Teorias sobre a causalidade da saúde e da doença}

\section{Causa - o que produz um resultado!!!}

\section{Aspectos a considerar:}

1 - A mesma causa pode produzir resultados diferentes;

2 - Os mesmos resultados podem resultar de causas diferentes;

3 - As causas e os seus resultados podem ser dificilmente relacionáveis. 


\section{Teorias sobre a causalidade da saúde e da doença}

\section{Causa vs Efeito}

“Não morremos porque estamos doentes...

Adoecemos porque somos mortais."

Bichat (1771-1802) 


\section{Teorias sobre a causalidade da doença}

1- Período Anterior ao desenvolvimento científico

\section{Teoria da Vontade Divina}

Teoria da Influência Astral

Teoria dos Humores (Sangue, Bilis, Pituita - cérebro e atrabilis ou Bilis Negra - baço)

\section{Teoria dos Miasmas}




\section{Teorias sobre a causalidade da doença}

\section{1-Teoria da Vontade Divina}

A religião e a medicina persistem indissociáveis durante séculos...

A saúde é um prémio...

A doença é um espirito demoníaco...

A doença é uma punição resultante de um pecado ou maldição...

A doença é uma fonte de purificação... 


\section{Teorias sobre a causalidade da doença}

\section{2 - Teoria da Influência Astral}

Alguns alinhamentos dos astros eram a causa das epidemias e de ouras calamidades que periodicamente assolavam a humanidade...

A Universidade de Paris, no séc. XIV considerou a cólera divina e uma má conjugação astral eram causas das epidemias de peste "negra", que na época dizimava populações inteiras na Europa. 


\section{Teorias sobre a causalidade da doença}

\section{3 - Teoria dos Humores}

A doença resultava do desequilíbrio entre os quatro humores vitais:

1) Sangue

2) Bílis

3) Pituita (Cérebro)

4) Atrabílis ou Bilis Negra (baço)

Hipócrates foi um dos principais difusores desta doutrina, que apesar de errada, foi fundamental para expulsar os deuses e os demónios da medicina... 


\section{Teorias sobre a causalidade da doença}

\section{3 - Teoria dos Humores}

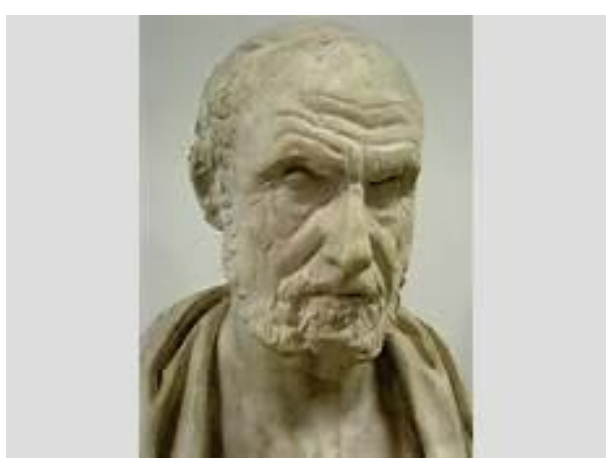

O estado da saúde/doença resulta do desequilíbrio entre os 4 humores vitais com - ambiente (ar, clima, alimentação, condições de trabalho...)

- A doença resulta de causas naturais;

- O organismo humano possui um poder natural de cura que compete aos médicos auxiliar. 


\section{Teorias sobre a causalidade da}

doença

\section{3 - Teoria dos Humores}

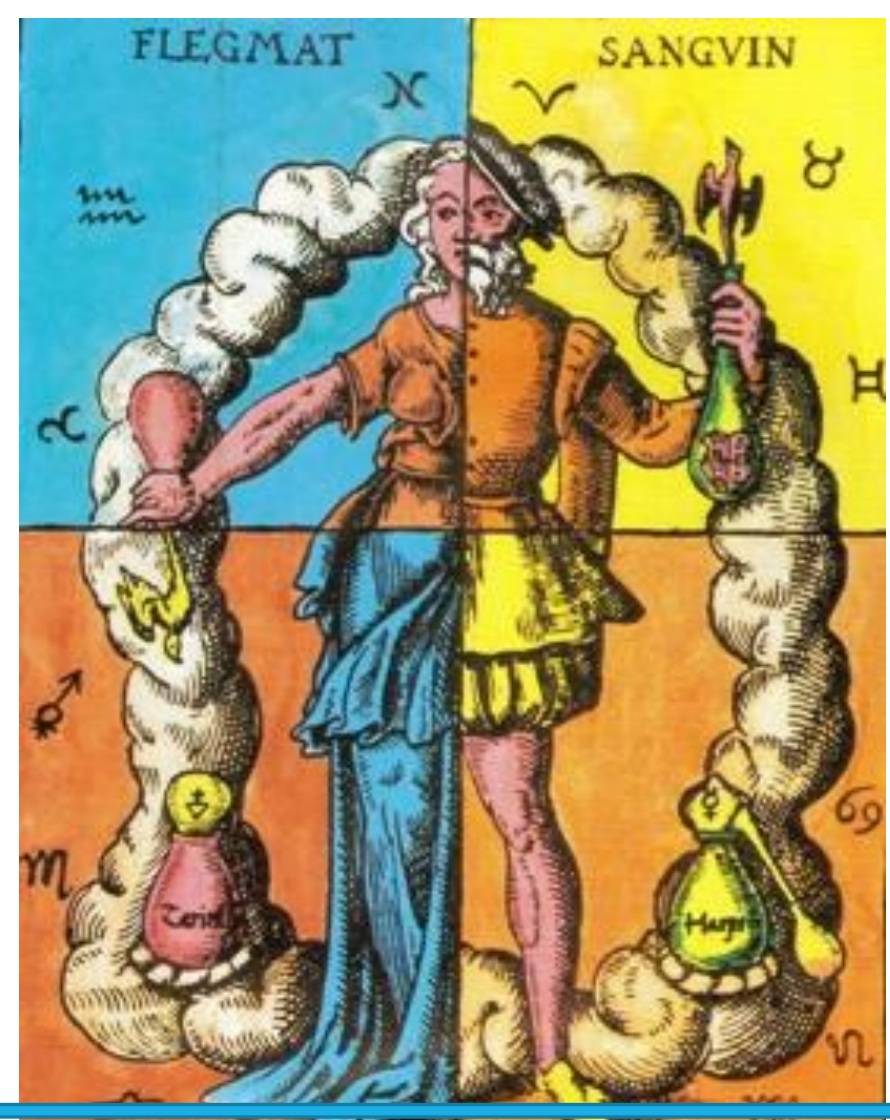

\section{Teoria dos Humores}
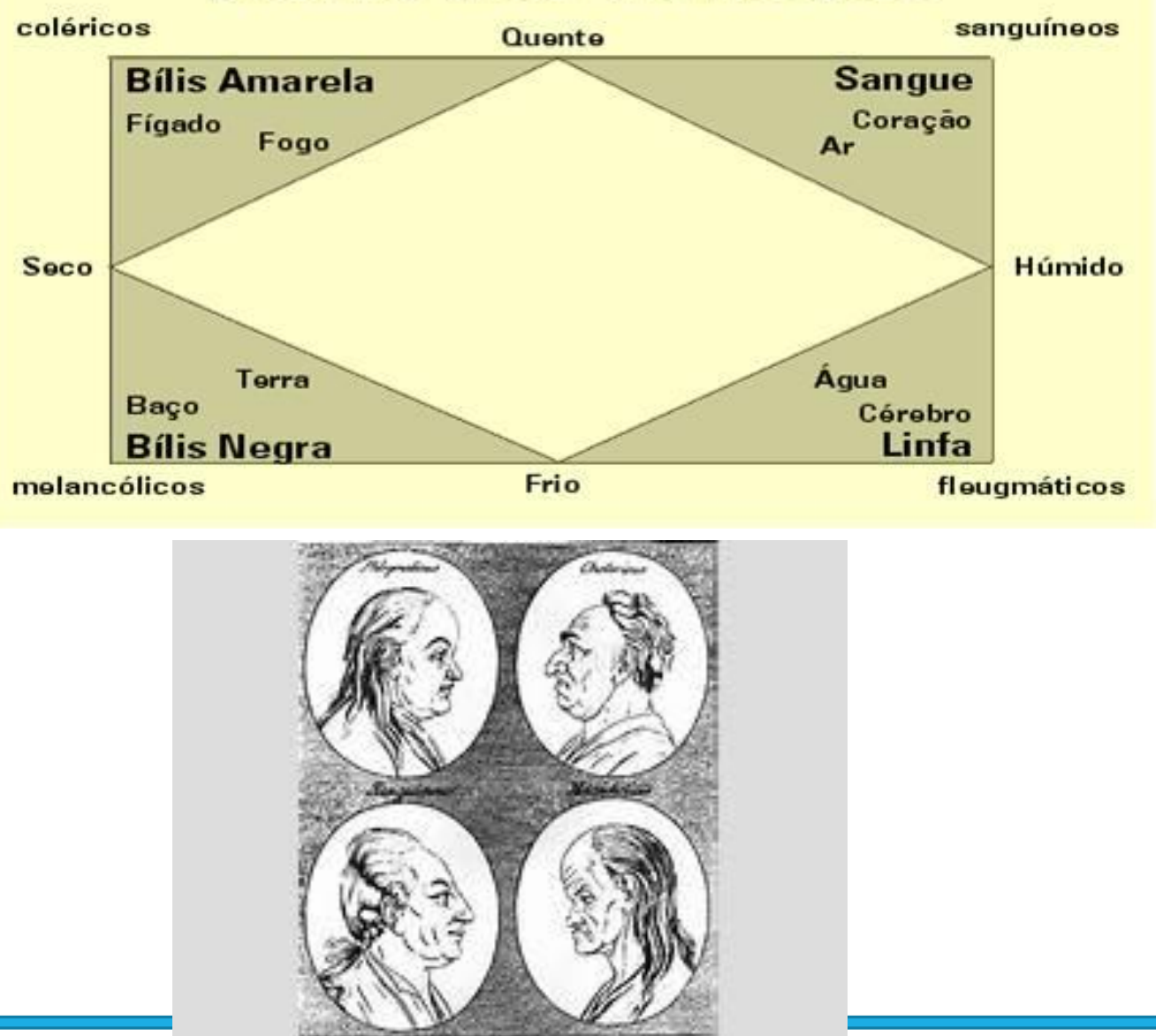

Saúde Clínica e Saúde Pública, Denise Capela dos Santos, 2018 


\section{Teorias sobre a causalidade da doença}

\section{3 - Teoria dos Miasmas}

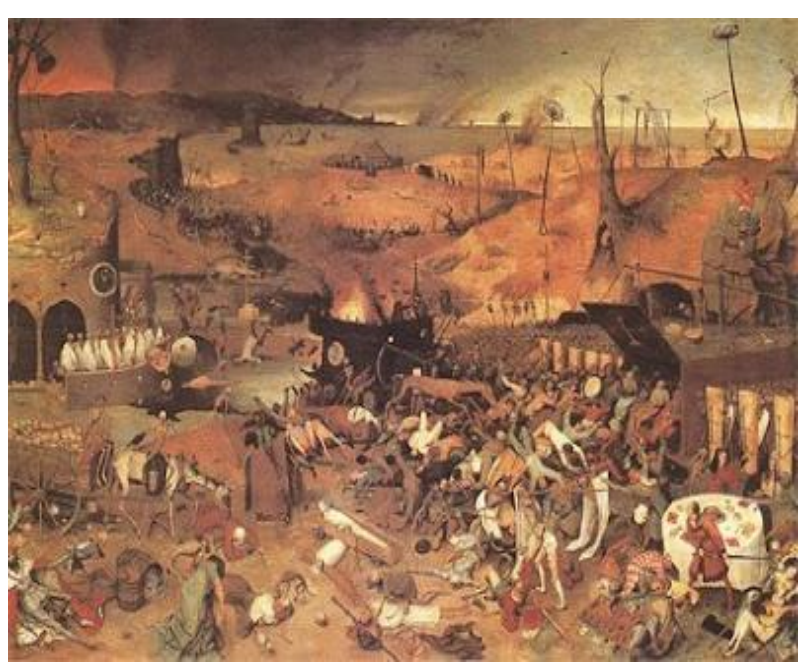

As doenças ou pestilências propagavam-se através do ar conspurcado por emanações nocivas de matéria orgânica.

Atinge 0 apogeu na Idade Média;

Persiste até ao advento da Era bacteriológica (Séc. XIX).

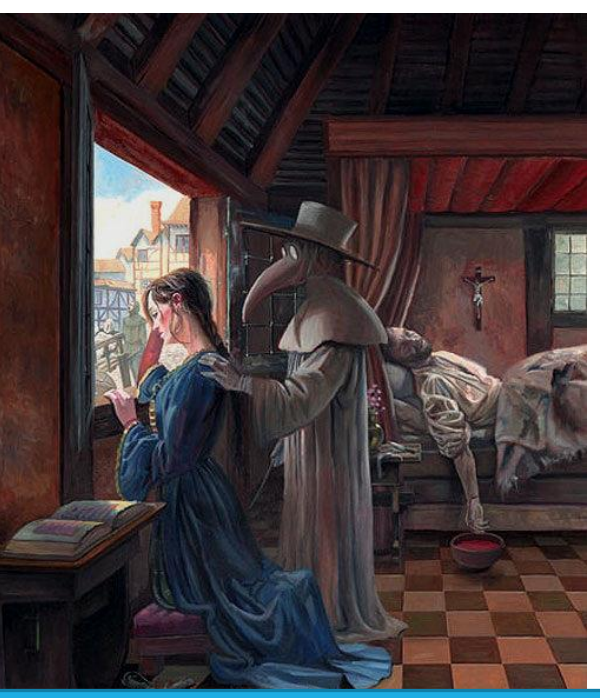




\section{Teorias sobre a causalidade da doença}

\section{Doenças actuais cuja designação provém das teorias não}

científicas dobre a causalidade da doença...

Influenza - a gripe resultaria de espíritos demoníacos (Teoria da Vontade Divina);

Malária - A doença resultava da exposição a maus ares (Teoria dos Miasmas);

Cólera (Teoria dos Humores) 
Teorias sobre a causalidade da doença

\section{2- Período do Desenvolvimento Científico da Saúde}

A. Teoria do Germe;

B. Teoria da Causalidade Múltipla;

C. Teoria da Causalidade Ambiental;

D. Teoria da Causalidade Comportamental;

E. Teoria da Causalidade Genética;

F. Teoria da Saúde como um Produto Social. 


\section{Teorias sobre a causalidade da doença}

\section{A. Teoria do Germe}

A doença resulta da presença no doente de organismos externos, os germes ou micróbios.

1696 - Antonie Von Leeuwenhoeck detecção de animáculos.

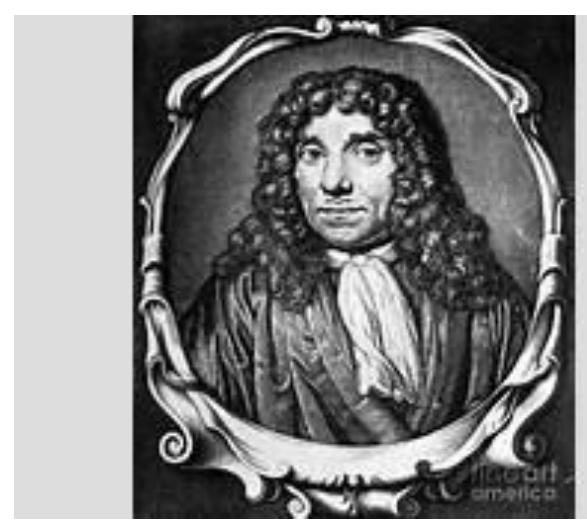




\section{Teorias sobre a causalidade da}

doença

1880 - Koch e
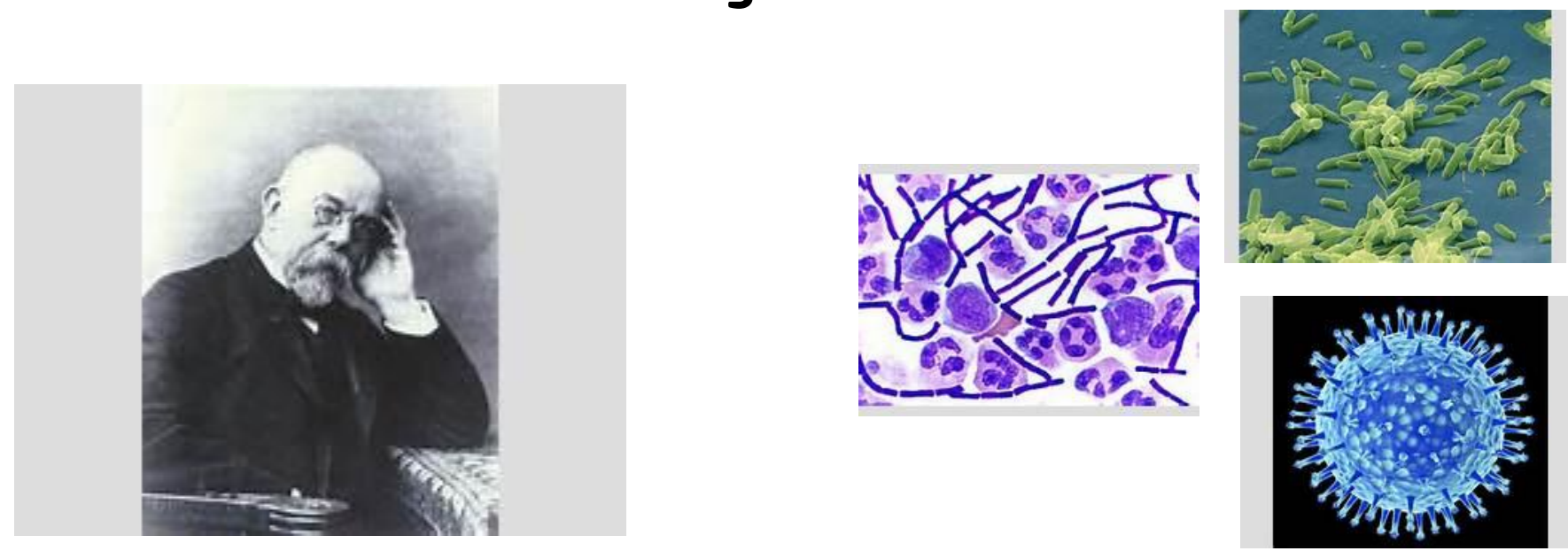

Pasteur demonstraram que algumas bactérias eram agentes etiológicos de doenças
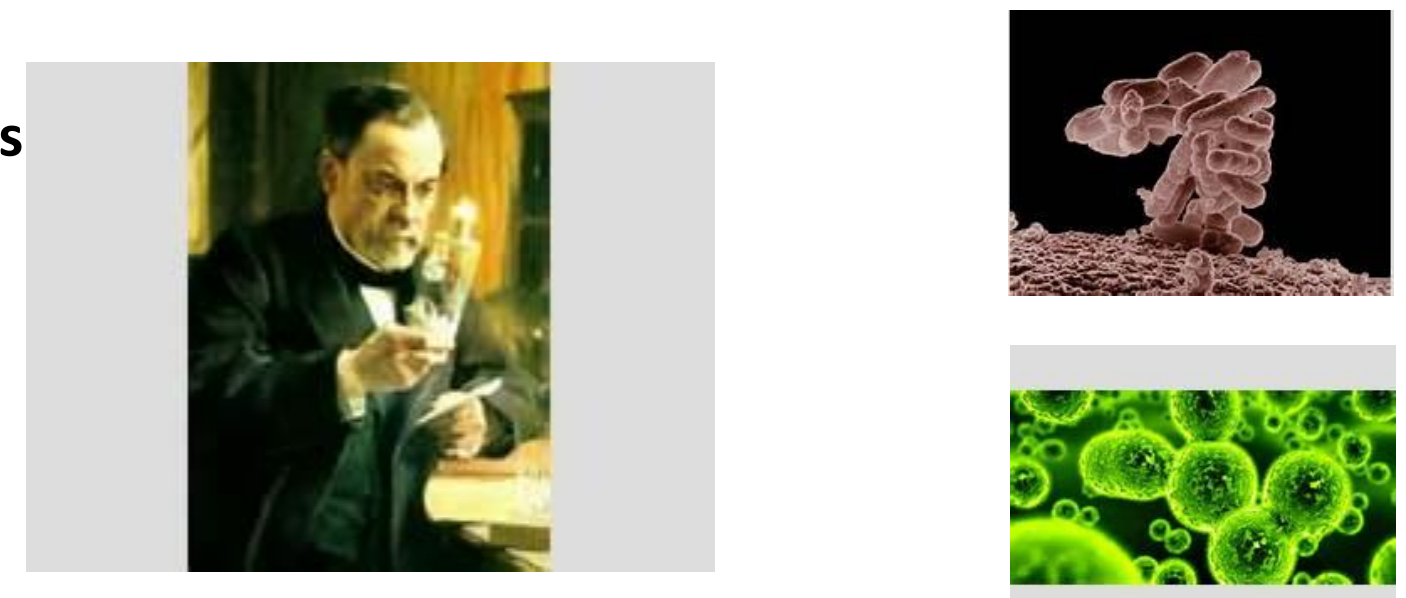


\section{Teorias sobre a causalidade da doença}

\section{POSTULADOS DE KOCH - 1882}

1 - 0 agente deve estar em cada caso de doença e deve poder ser isolado em cultura pura.

2- $O$ agente não pode ser encontrado em casos de outra doença.

3- Uma vez isolado, o agente deve ser capaz de reproduzir experimentalmente a doença em animais de laboratório.

4- $O$ agente deve poder ser recuperado a partir da doença produzida. 


\section{Teorias sobre a causalidade da doença}

- Assumiu grande importância para o diagnóstico de algumas doenças infecciosas e para a divulgação de algumas estratégias (vacinação);

- Teve pouco impacto na luta contra a doença pois não dispunha de arsenal terapêutico adequado nem considerava o contexto social em que a doença ocorria. 


\section{Teorias sobre a causalidade da doença}

\section{B. Teoria da Causalidade Múltipla}
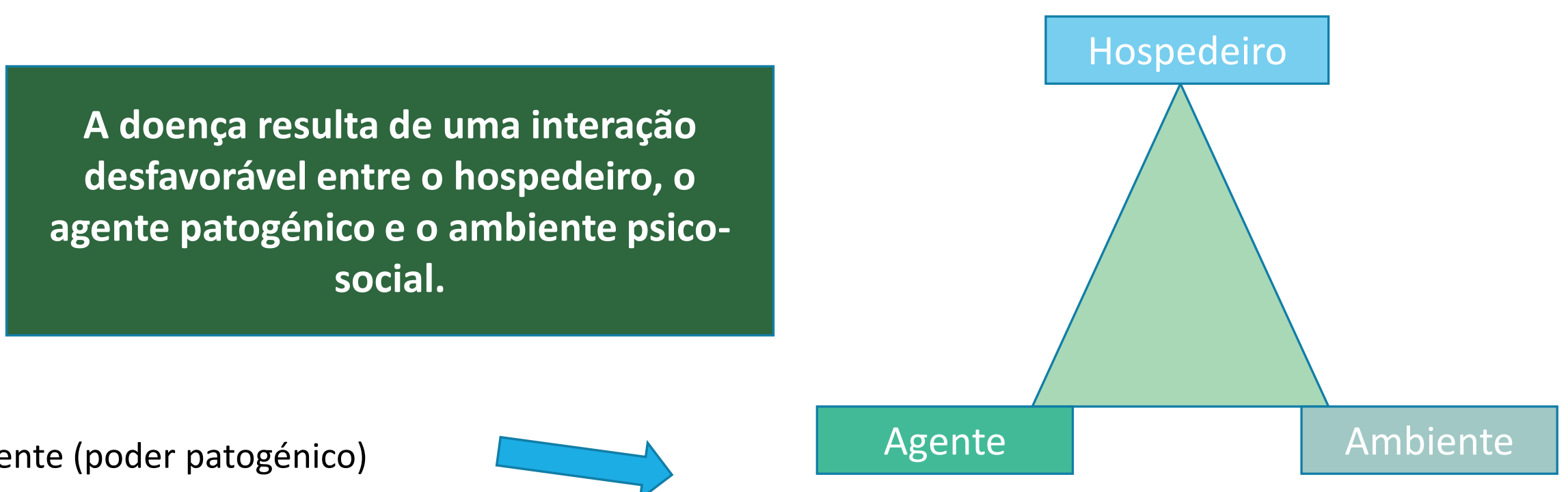

Agente (poder patogénico)

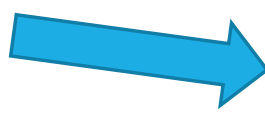

Doença

Ambiente (favorável ou desfavorável)

Hospedeiro (mecanismos de defesa)

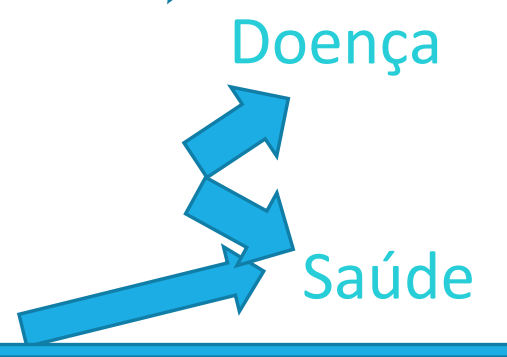




\section{Teorias sobre a causalidade da doença}

1. Saúde= Equilíbrio

2. Doença: aumento da virulência ou patogenicidade do agente causal.

3. Doença $=$ diminuição das defesas do hospedeiro.

4. Doença: o ambiente sofre uma alteração que é desfavorável.
Fatores ambientais

que produzem

ESTIMULO

à doença
AGENTE DA DOENÇA

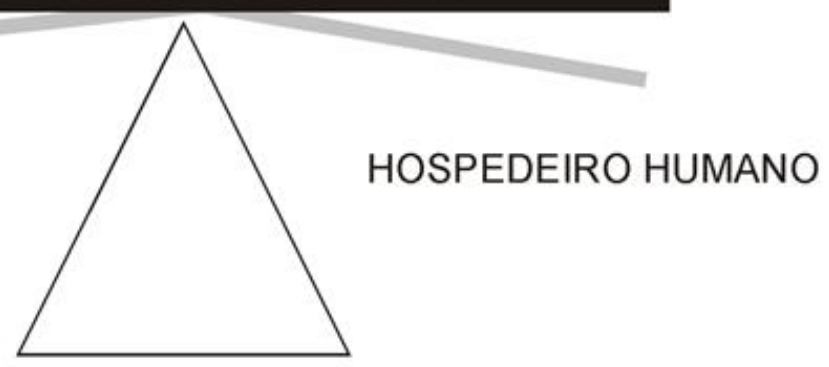




\section{Teorias sobre a causalidade da doença}

\begin{tabular}{|l|l|l|}
\hline FATORES & $\begin{array}{l}\text { Contribuição para } \\
\text { redução } \\
\text { mortalidade (\%) }\end{array}$ & $\begin{array}{l}\% \text { dos custos } \\
\text { relativamente ao } \\
\text { total de despesas } \\
\text { em saúde }\end{array}$ \\
\hline Genéticos / Biológicos & 27 & 7,9 \\
\hline Ambientais & 19 & 1,6 \\
\hline Comportamentais & 43 & 1,5 \\
\hline $\begin{array}{l}\text { Político-Sociais/ } \\
\text { Sistemas de Saúde }\end{array}$ & 11 & 90 \\
\hline
\end{tabular}




\section{Teorias sobre a causalidade da doença}

\section{Postulados de Clark}

- A doença é uma resultante de um desequilíbrio de forças entre o agente e o hospedeiro.

- O grau de desequilíbrio depende das características do agente e do hospedeiro.

- As características do agente, do hospedeiro e a interação entre eles são condicionadas pelo ambiente.

O conceito de agente etiológico é substituido pela noção probabilistica de risco, que quantifica a importância relativa dos diversos factores associados ao agente, ao hospedeiro e ao ambiente. 


\section{Teorias sobre a causalidade da doença}

C. Teoria da Causalidade Ambiental

A doença resulta de alterações do ambiente, muito rápidas ou intensas, que ultrapassam a capacidade de adaptação do Homem.

- Fundamenta-se no conceito ecológico de saúde;

- As formas de organização das sociedades modernas e o desrespeito pela natureza são responsabilizados pela doença. 


\section{Fatores Ambientais}

Ecologia médica: Área que estuda a interação do Homem com o ecossistema (sistema complexo de plantas e animais que, conjuntamente com todos os fatores físicos circundantes formam uma comunidade e vivem em equilíbrio). 


\section{Fatores Ambientais}

1. Ambiente Físico:

Contaminação Biológica dos Suportes dos Ecossistemas (Ar, Água e Solo)

Doenças Infeciosas e Transmissíveis; Surtos Epidémicos

Contaminação Química/ Física dos Suportes dos Ecossistemas (Ar, Água e Solo)

Doenças Crónicas e Degenerativas; Intoxicações Agudas
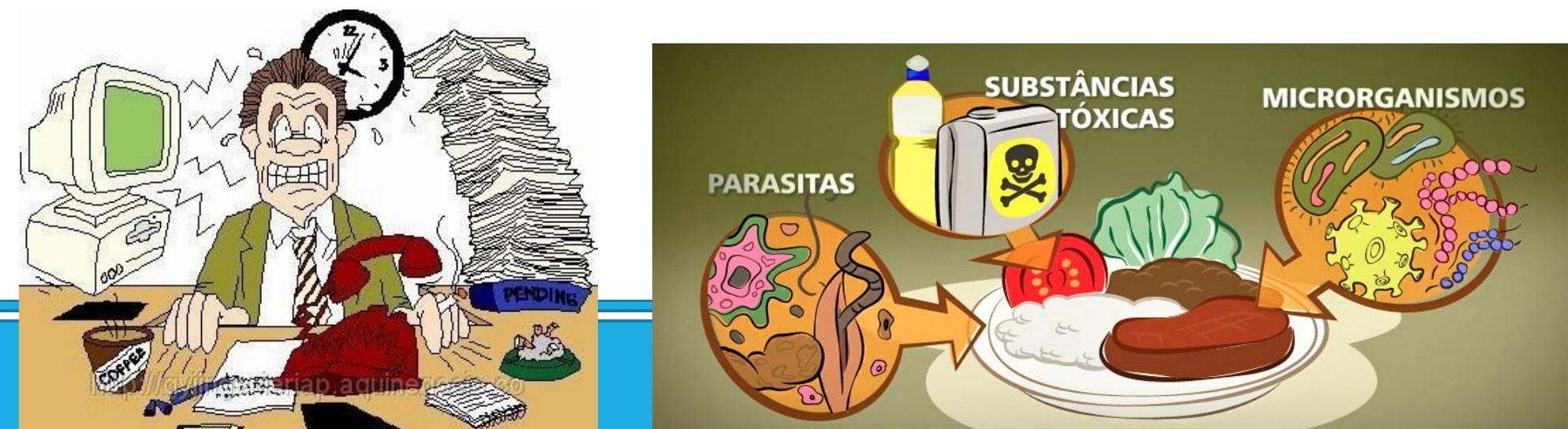


\section{Fatores Ambientais}

Riscos para a saúde de origem hídrica:

Poluentes:

Metais pesados, detergentes, partículas radioativas, pesticidas, hidrocarbonetos, detritos (lixos)

Contaminantes:

Bactérias, Vírus, Fungos e Parasitas
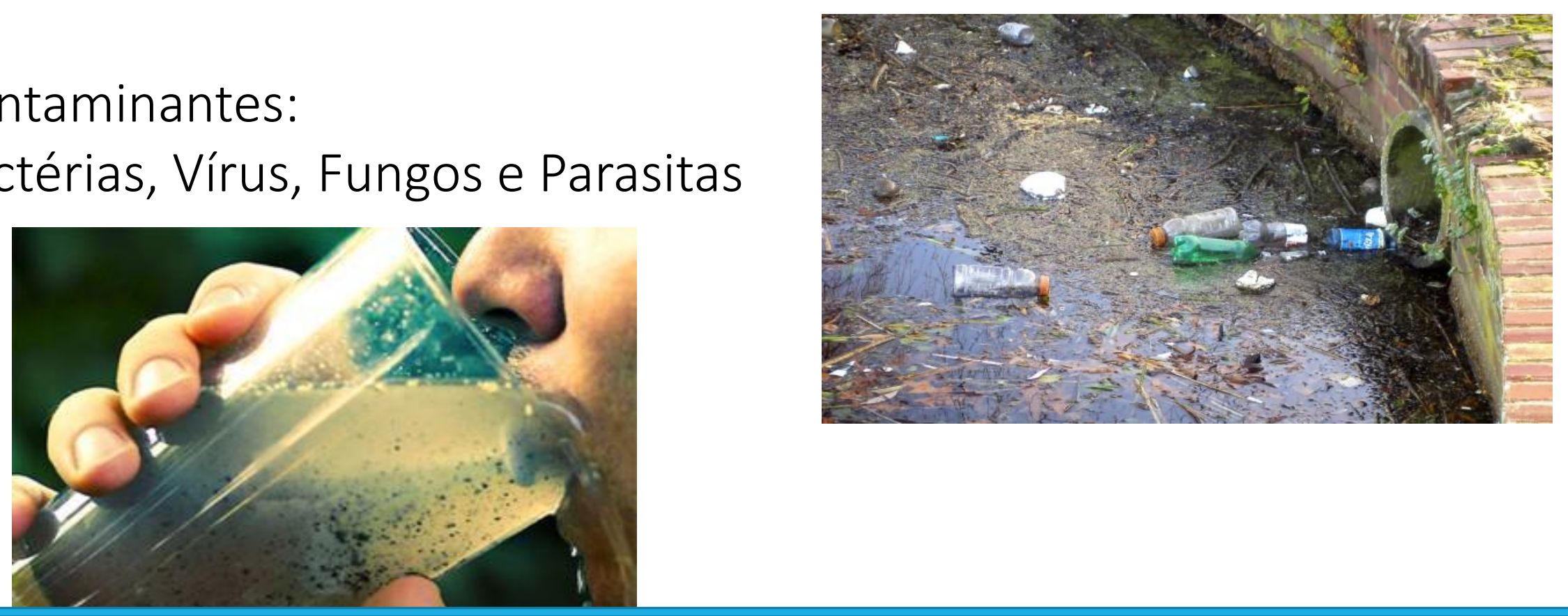


\section{Fatores Ambientais}

Riscos para a saúde de origem no solo:

Poluentes:

Metais pesados (DDT na cadeia alimentar), partículas radioativas, pesticidas, detritos (lixo)

Contaminantes: Bactérias, Fungos, Parasitas
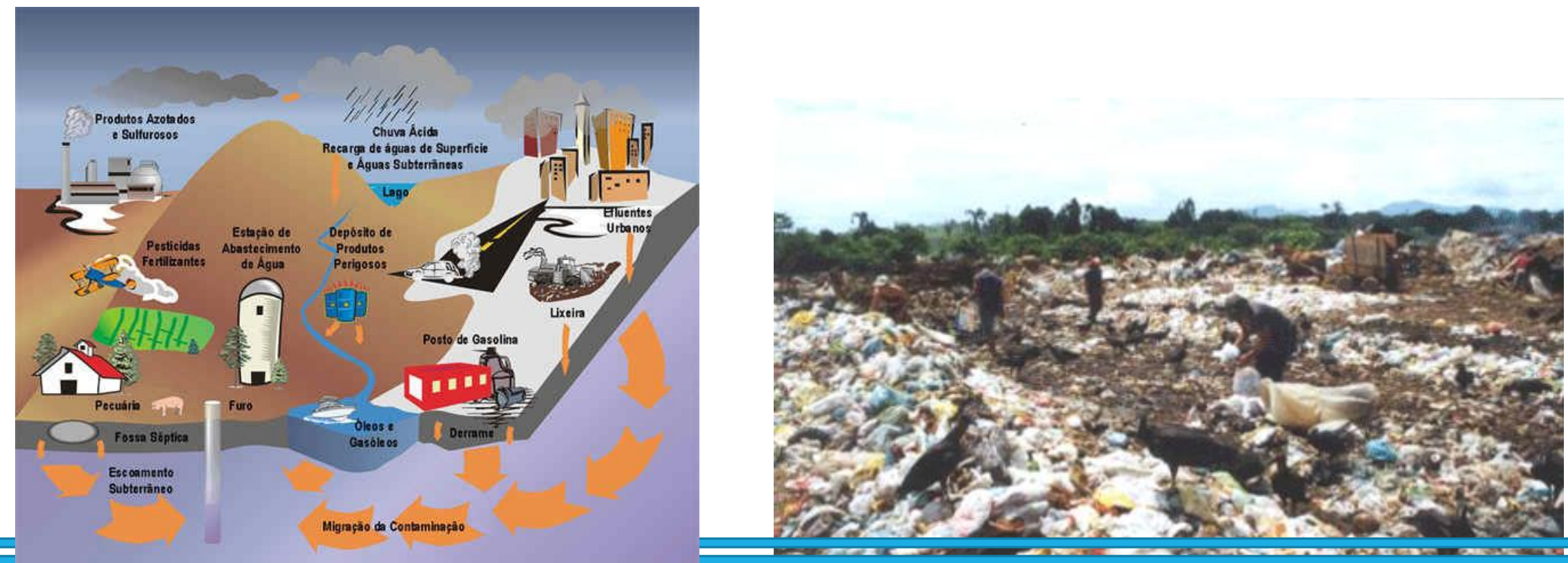

Saúde Clínica e Saúde Pública, Denise Capela dos Santos, 2018 


\section{Fatores Ambientais}

\section{Riscos para a saúde de origem aérea:}

Poluentes:

Metais pesados (chumbo e mercúrio), gases (ozono, $\mathrm{CO}$ e CO2, Óxido de enxofre e de azoto), partículas sólidas (fumos)

Principais doenças: asma, bronquite, cancro, enfizema pulmonar, infeções pulmonares (tuberculose), doenças alérgicas

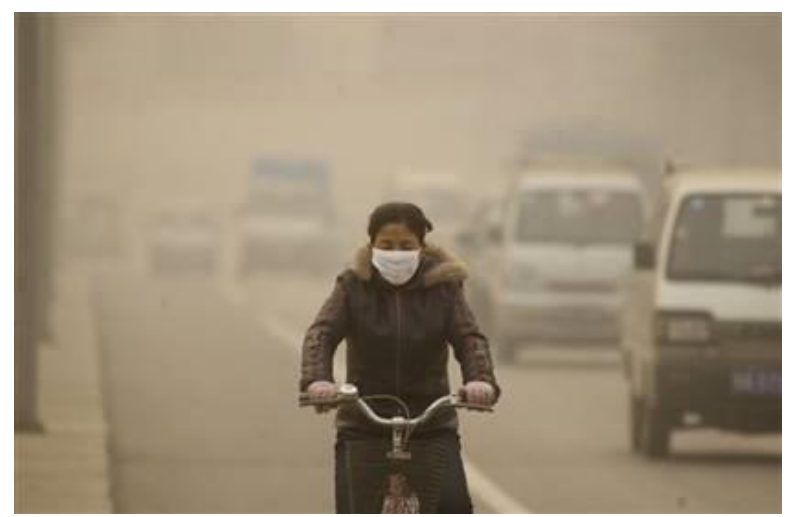




\section{Fatores Ambientais}

Principais estratégias de combate à poluição atmosférica:

1. Redução: Instalação de dispositivos adequados à redução do teor de poluentes;

2. Dispersão: Optimização da capacidade de dispersão dos poluentes para as camadas mais altas da atmosfera;

3. Reconversão: Substituição por tecnologias menos poluentes;

4. Planeamento ecológico: escolha adequada dos locais de implantação das indústrias poluentes (topografia, meteorologia, etc.) e instalação de zonas tampão. 


\section{Fatores Ambientais}

\section{Intervenções:}

1. Saneamento: Conjunto de ações indispensáveis à prevenção da insalubridade do ambiente e/ou manutenção do ambiente a níveis seguros

$\checkmark$ Abastecimento de água potável (captação, tratamento, distribuição);

$\checkmark$ Evacuação higiénica e tratamento de águas residuais urbanas e industriais;

$\checkmark$ Evacuação higiénica e tratamento de lixos

$\checkmark$ Medidas contra poluição de águas superficiais;

$\checkmark$ Medidas contra a proliferação de vetores;

$\checkmark$ Medidas contra a poluição atmosférica;

$\checkmark$ Medidas de higiene e salubridade ambiental

$\checkmark$ Urbanismo

$\checkmark$ Medidas de salubridade de géneros alimentícios (produção, tratamento, conservação, distribuição e consumo);

$\checkmark$ Medidas de salubridade nas escolas, hospitais e ruas. 


\section{Fatores Ambientais}

Intervenções:

2. Educação relativa ao ambiente: Identificação de riscos ambientais e participação na sua solução;

3. Construção de ambientes saudáveis: Dotar as comunidades de infra-estruturas que thes permitam controlar/ eliminar riscos ambientais e ordenar os espaços segundo uma perspetiva ecológica;

4. Adoção de políticas de desenvolvimento sustentado.

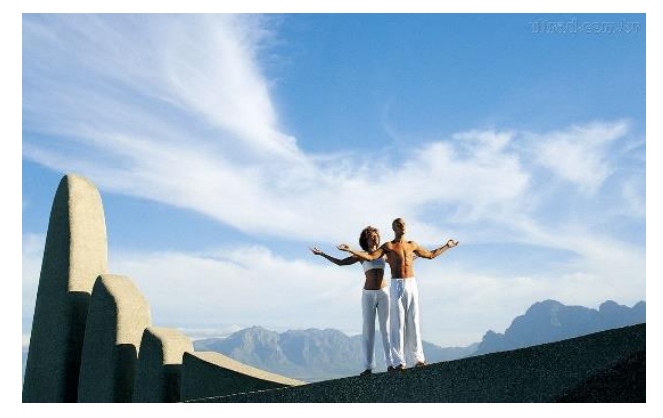


2. Ambiente Biológico

Maior concentração de reservatórios de zoonoses Proliferação de vetores

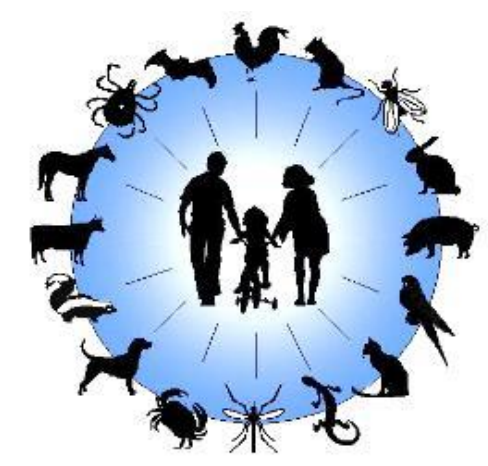

Doenças Infeciosas e Transmissíveis; Surtos Epidémicos

3. Ambiente Social

Degradação do habitat, Concentração populacional nas grandes cidades

Patologias sociais

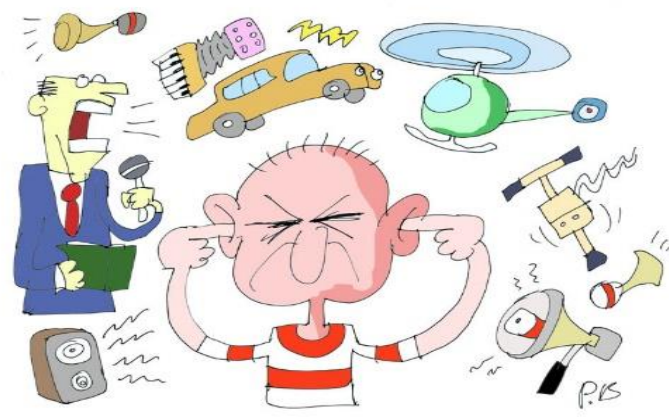

Poluição sonora: O ruído tem impacto negativo na saúde acima dos 65 db (20\% populaão portuguesa). Aumenta a constrição dos vasos sanguíneos, a pressão arterial, o risco cardíaco, o risco de surdez e o comportamento violento. 


\section{Teorias sobre a causalidade da}

\section{doença}

D. Teoria da Causalidade Comportamental

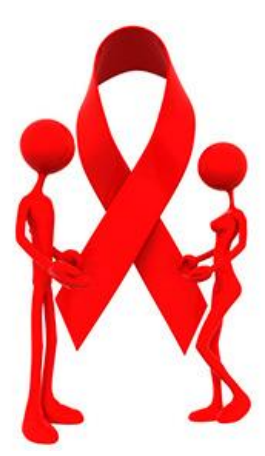

- A prevenção e combate a doença centra-se em estratégias de Promoção da Saúde;

- O doente é o principal responsável pela ocorrência da doença que 0 afecta.

"É aquilo que cada um faz no dia à dia que determina o seu estado de saúde, a probabilidade de adoecer, o tipo de doença e a duração da sua vida." (Lester Breslow) 


\section{Fatores Comportamentais}

Prática de desporto/ exercício físico pelo menos 1x/semana Excesso de peso: IMC 27-29,9

Obesidade: IMC maior ou igual a 30

Consumo de álcool

Consumo de tabaco

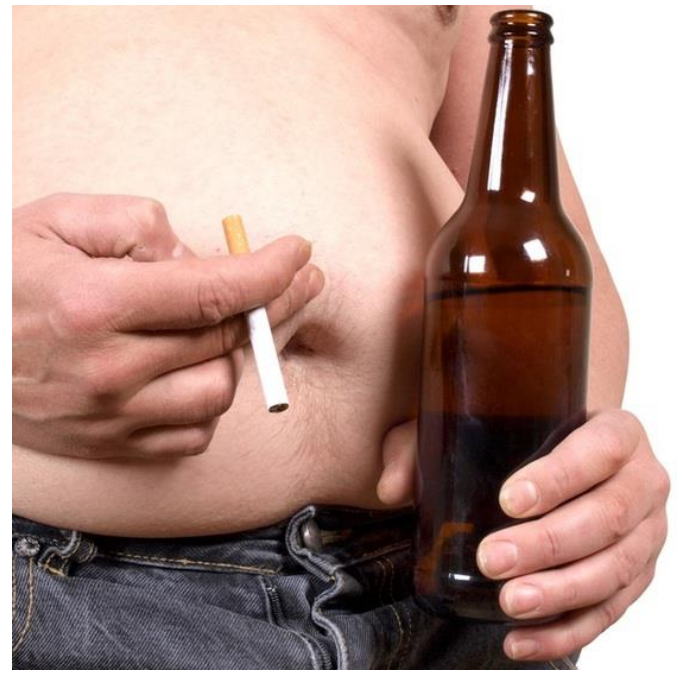




\section{Teorias sobre a causalidade da doença}

\section{E. Teoria da Causalidade Genética/Biológica}

A doença resulta da maior suscetibilidade do individuo à doença determinada geneticamente.

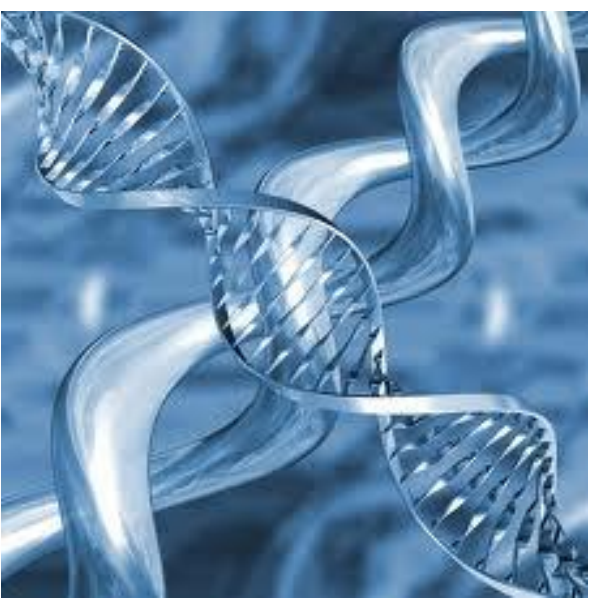

O combate à doença centra-se em estratégias de Prevenção Genética.

O doente, a sua familia e os seus genes são os principais responsáveis pela ocorrência da doença que o afecta. 


\section{Fatores Genéticos}

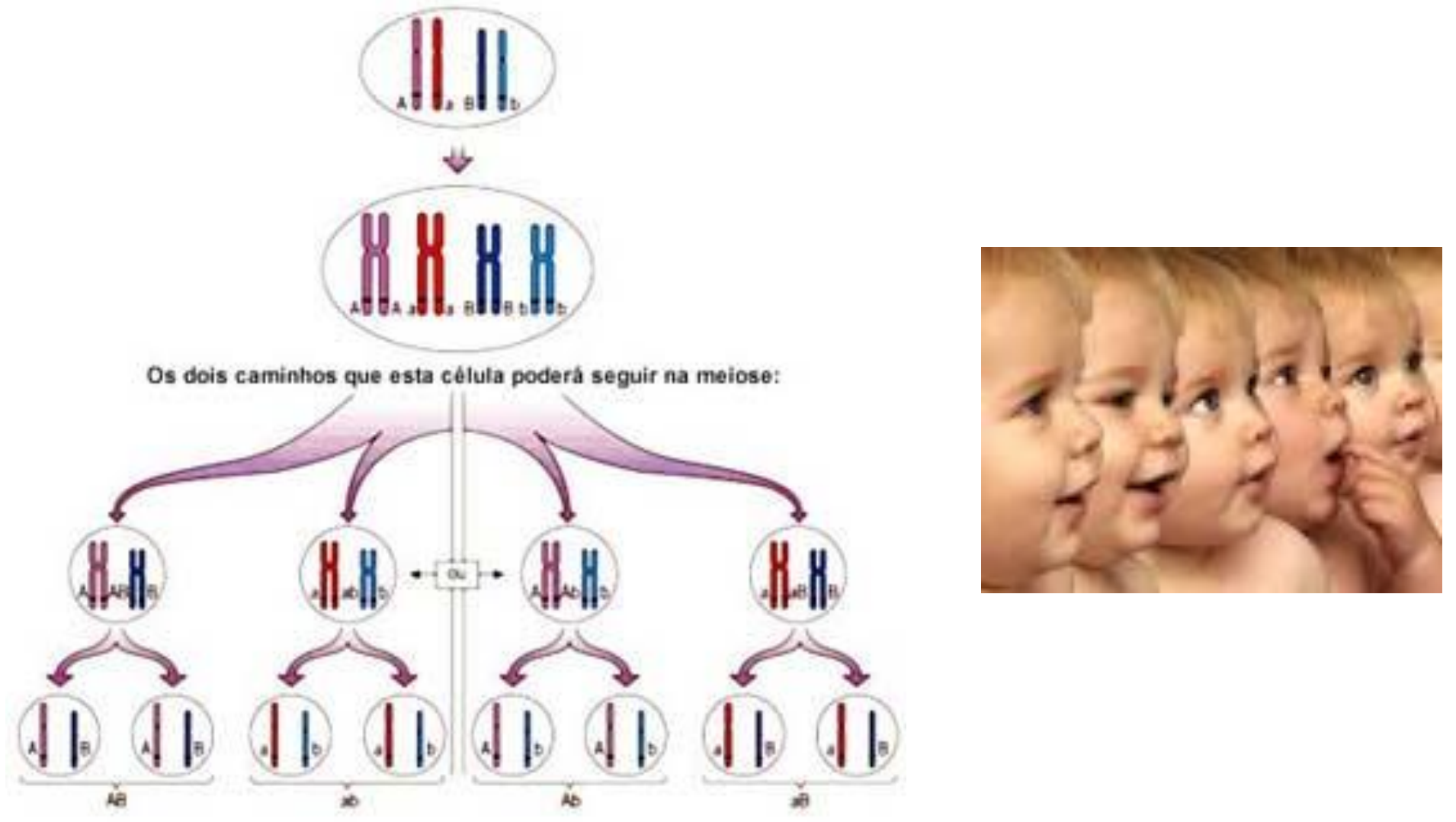




\section{Fatores Genéticos}

A. Doenças genéticas (mutação de um número limitado de genes): Paramiloidose, Fenilcetonúria, Hemofilia

B. Anomalias cromossómicas: Trissomia 21, Síndroma Turner OX, Síndroma Klinfelter XXY

C. Doenças multifatoriais (genética + ambiente: Espinha bífida, HTA, Diabetes, etc.)

"Qualquer mulher que engravide tem 3,3\% de probabilidade de ter uma criança com malformação congénita." Frazer Roberts

Malformações congénitas

(Major Portugal: 20 a 30/1000NV) 


\section{Fatores Genéticos}

Prevenção:

- Deteção e acompanhamento de gravidez de risco (Diagnóstico pré-natal)

- Rastreio Sistemático em Recém Nascidos (Teste do Pezinho: Paramiloidose e Fenilcetónúria)

- Registo de Malformações congénitas

Prevenção genética: Casal consanguíneo, casal com familiares portadores da doença, casal portador da doença genética. Heredograma, Cariótipo, Testes enzimáticos e bioquímicos, Redução exposição a agentes mutagénicos. 


\section{Fatores Genéticos}

Embriofetopatias (agentes mutagénicos): Drogas, medicamentos (Talidomida, Isotretinoína, Benzodiazepinas, IECAS, AINES, Varfarina, Tetraciclina, etc.), infeções (toxoplasmose, rubéola, sífilis), RX, Carências Vitamínicas, tabaco

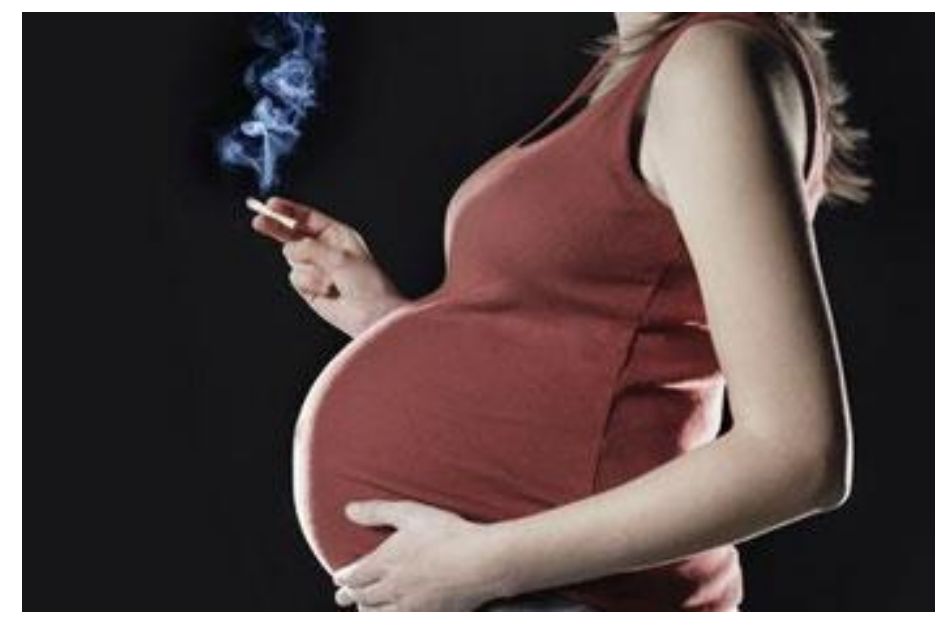




\section{Teorias sobre a causalidade da doença}

F. Teoria da Saúde como Produto Social

A doença resulta dos modelos de organização social, da forma como é distribuída a riqueza e como são alocados os recursos.

O combate à doença centra-se na satisfação das necessidades básicas dos indivíduos e grupos:

1) Alimentação;

2) Habitação;

3) Emprego;

4) Paz e segurança.
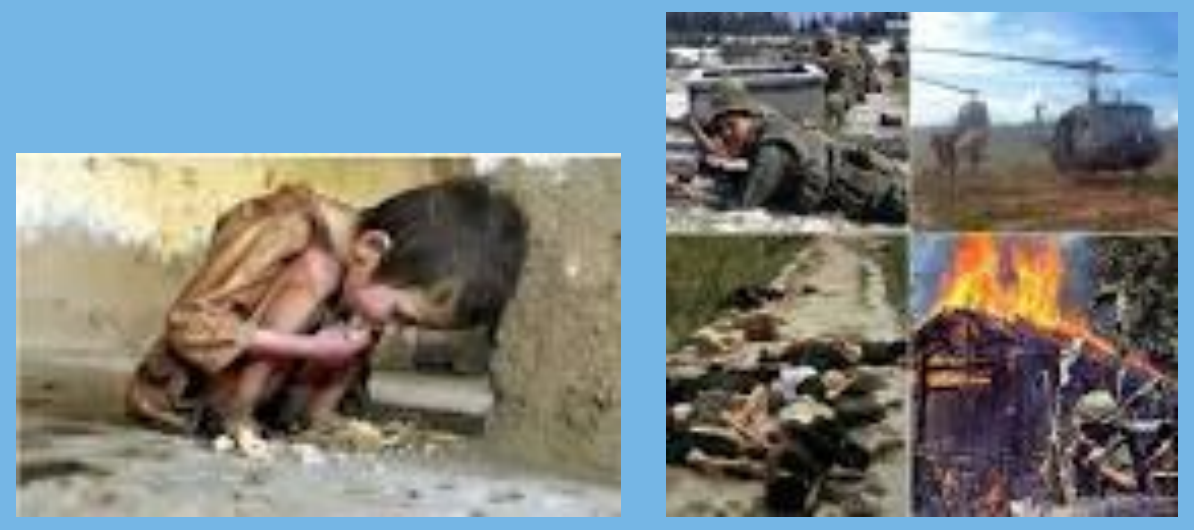


\section{Fatores Político-sociais}

$>$ Um maior potencial de saúde origina maior produtividade;

$>\mathrm{O}$ investimento em saúde gera desenvolvimento e dividendos sanitários (poluição ar água e solo, esgotamento de recursos naturais, degradação do habitat), sociais (aumento de patologias sociais) e económicos (aumento de custos em saúde e tecnologia - travão ao desenvolvimento);

$>$ O grau de desenvolvimento condiciona os padrões de morbilidade e de mortalidade de uma população.

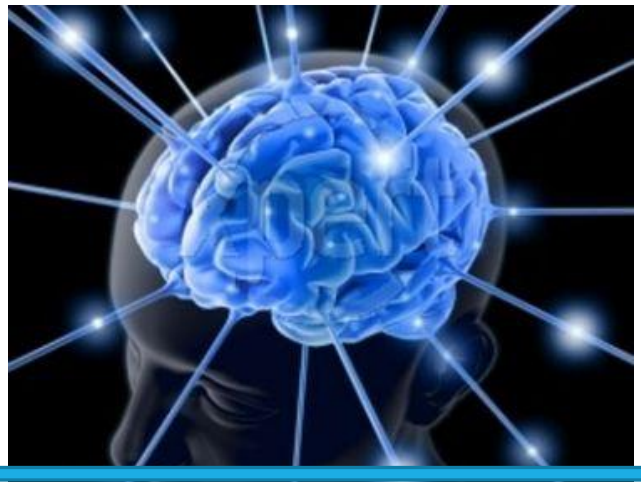




\section{Fatores Político-sociais}

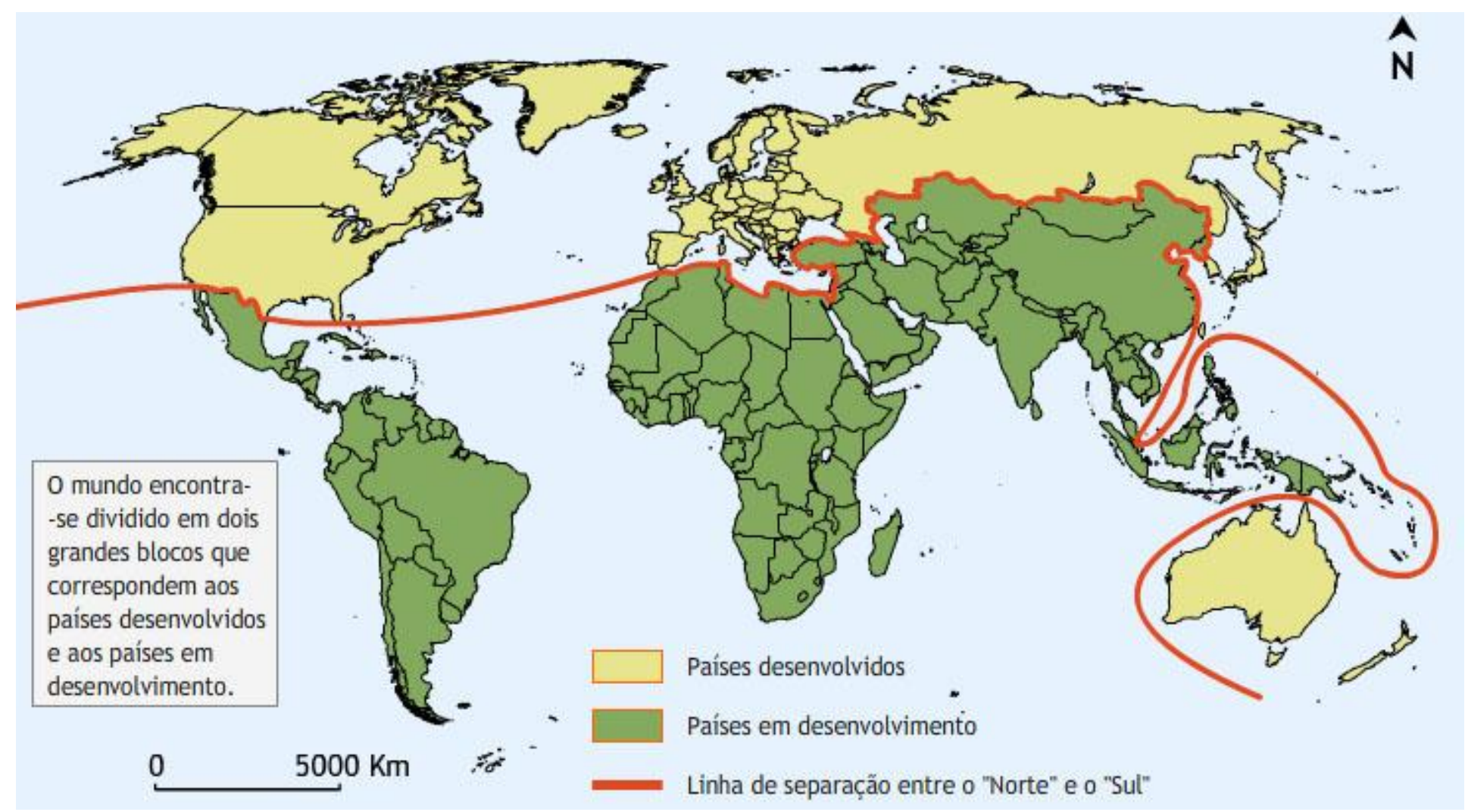

Saúde Clínica e Saúde Pública, Denise Capela dos Santos, 2018 


\section{Fatores Político-sociais}

$>$ Mortalidade e morbilidade em países em vias de desenvolvimento:

Prevalência elevada de HIV, Tuberculose e Malária;

Carências nutricionais/fome;

Insalubridade ambiental;

Elevada mortalidade infantil (maior de 100/1000NV);

N. ㅇ insuficiente de técnicos de saúde;

Baixa acessibilidade a cuidados de saúde e medicamentos essenciais

Esperança de vida à nascença inferior a 55 anos. 


\section{Fatores Político-sociais}

> Mortalidade e morbilidade em países desenvolvidos:

Envelhecimento da população;

Elevada mortalidade por doenças cardiovasculares e cancro; Grande prevalência de doenças crónicas e problemas psicosociais;

Obesidade crescente; Incidência de "novas" patologias infeciosas;

Custos muito elevados na prestação de cuidados de saúde. 


\section{Teorias sobre a causalidade da doença}

\section{A melhoria das condições de vida e de trabalho teve um maior impacto}

na Saúde Pública do que os progressos da medicina.

\section{Mckeown (1998)}

\section{The Wheel of Causation}

https://www.youtube.com/watch?v=QvJROF zuiAU

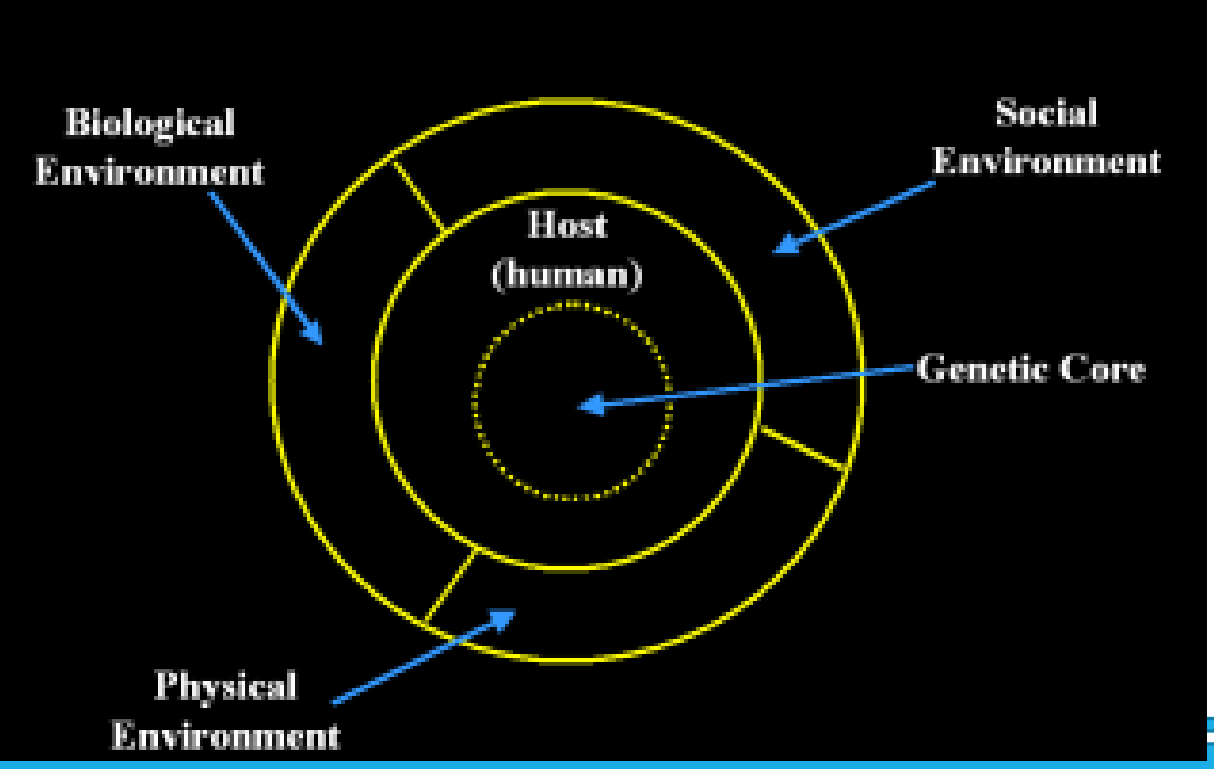
dos Santos, 2018 


\section{Teorias sobre a causalidade da doença}

\section{Causalidade Vs Associação}

\section{https://www.youtube.com/watch?v=QvJROFzuiAU}

Estudos observacionais

Estudos de Controlo Randomizado

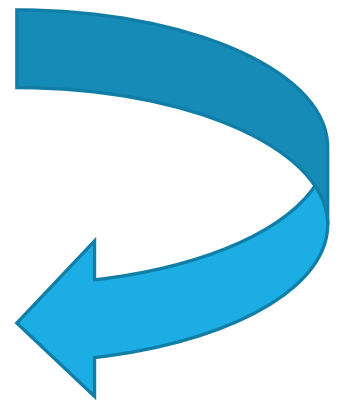

https://www.youtube.com/watch?v=9xb58td031A

https://www.youtube.com/watch?v=kKHx9T6XUIO

Grupos Controlo e Experimentais, Estudos duplamente cegos

https://www.youtube.com/watch?v=GMqrOdCx4Yg

Técnicas de amostragem: Amostras de conveniência, de resposta voluntária Simples Randomizada, Estratificada Randomizada e Multistage

https://www.youtube.com/watch?v=pTuj57uXWlk 


\section{Teorias sobre a causalidade da doença}

Estudos observacionais - Comparação de grupos não controlados por observação de uma determinada variável com outros grupos que não a têm e avaliação do efeito: Associação ou correlação

N.ㅇ de horas de estudo é causa de melhores notas num teste?

Estudos de Controlo Randomizado - Comparação de grupos saudáveis de hábitos controlados e idênticos, escolhidos aleatoriamente, em que existe intervenção com pelo menos duas variáveis: um toma um placebo e outro um fármaco, por exemplo, e avaliação do efeito: Causalidade

2 Tempos de escovagem + 2 Marcas da Pasta de Dentes = Nível de saúde oral ? 


\section{Teorias sobre a causalidade da}

Teia de causalidade doença

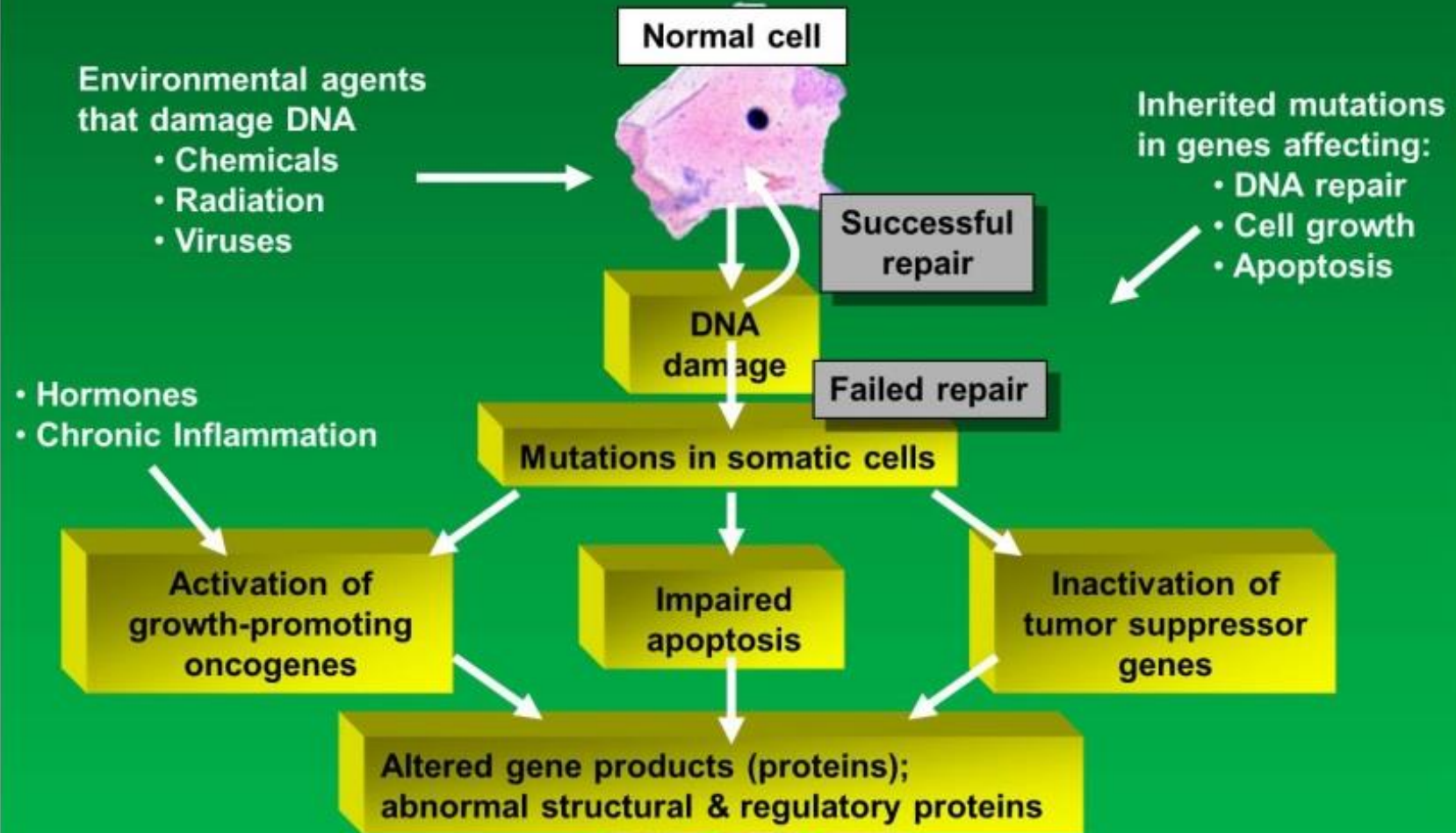

Environmental agents that damage DNA

- Chemicals

- Radiation

- Viruses

- Hormones

- Chronic Inflammation

Activation of growth-promoting oncogenes

\section{Normal cell}

$\bullet$

Inherited mutations

in genes affecting:

- DNA repair

- Cell growth

- Apoptosis

Altered gene products (proteins);

abnormal structural \& regulatory proteins

Inactivation of

Impaired tumor suppressor genes

Saúde Clínica e Saúde Pública, Denise Capela dos Santos, 2018 


\section{Teorias sobre a causalidade da}

Teia de causalidade

\section{doença}

\section{Web of Causation applied to Myocardial Infarction}

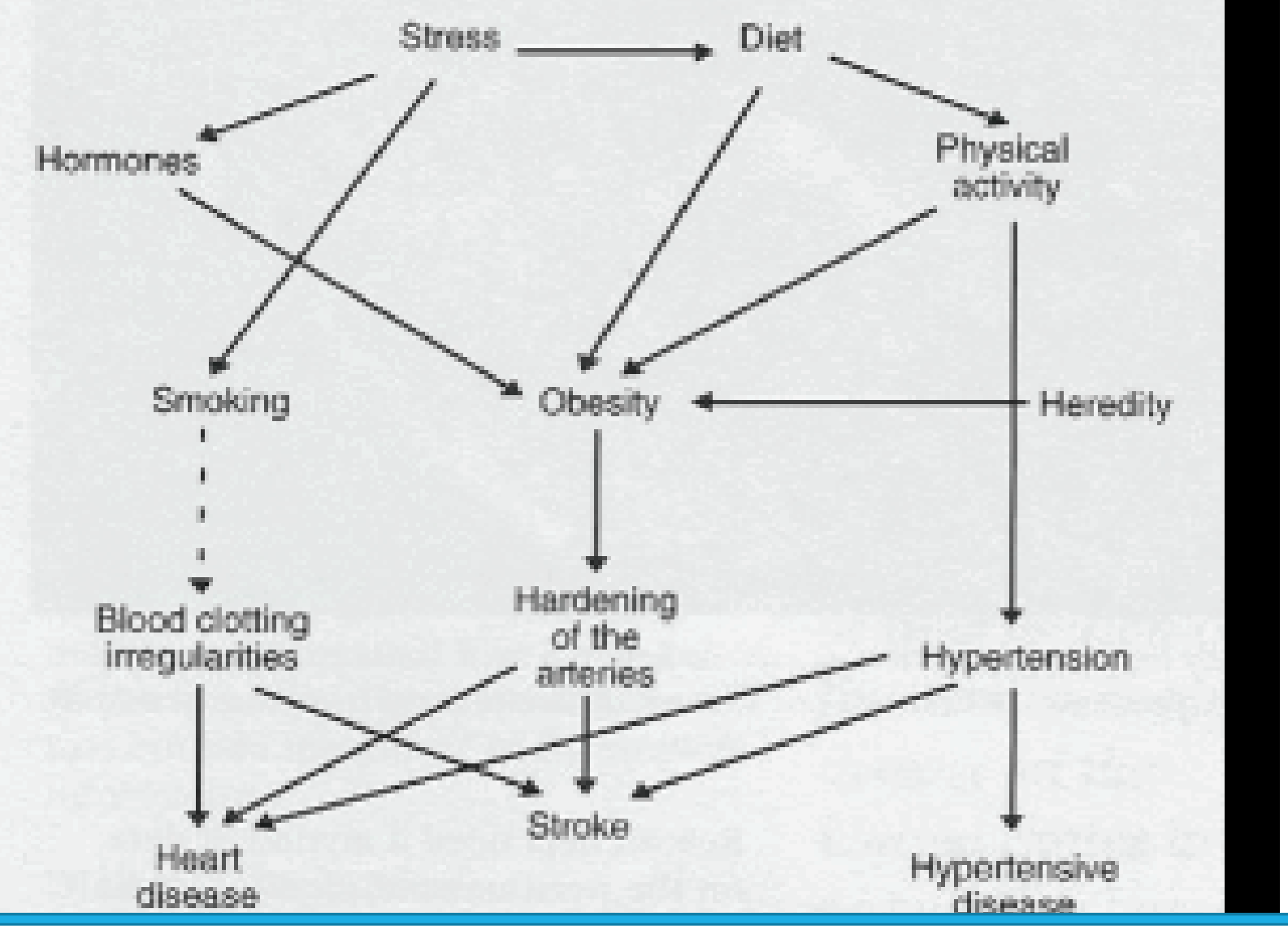

Saúde Clínica e Saúde Pública, Denise Capela dos Santos, 2018 


\section{Teorias sobre a causalidade da doença}

\section{EXERCÍCIO}

Como pode comprovar que a exposição solar causa tumores de pele?

Como pode comprovar que a prescrição de $20 \mathrm{mg}$ de Sinvastatina da Generis/dia causa a redução da mortalidade por obesidade?

Que tipo de técnica de amostragem escolheria para os estudos? Porquê? 


\section{Ensaios Clínicos}

https://www.youtube.com/watch?v=bctaWQTYHJc

Ética

https://www.youtube.com/watch?v=Ew2OmY Uer4

https://www.youtube.com/watch?v=VjqqaGOqUm8

Desenvolvimento de Medicamentos e ensaios clínicos em unidades de saúde

https://www.youtube.com/watch?v=3Gl0gAcw8rw

Patentes

https://www.youtube.com/watch?v=MZdt8nms9ms 


\section{Tipos de Ensaios Clínicos}

Ensaio Clínico Multicêntrico Multinacional: estudo realizado de acordo com um único protocolo, em mais de um centro de ensaio e em mais do que um país.

Ensaio Clínico Aberto: estudo em que tanto o investigador como o doente sabem qual a medicação que está a ser administrada.

Ensaio Clínico Aleatorizado: um ensaio em que todos os doentes são distribuídos ao acaso por dois ou mais grupos de tratamento.

Ensaio Clínico em Ocultação Simples: estudo em que o investigador sabe que tratamento que o doente está a receber, mas o doente não tem acesso a essa informação.

Ensaio Clínico em Dupla Ocultação: estudo em que nem o doente nem o investigador sabem qual o tratamento que o doente está a receber. 


\section{Fases dos Ensaios Clínicos}

\section{Fase I}

Tipo de Estudo

Sem objetivos terapêuticos

\section{Objetivo}

Avaliação inicial de Segurança e Tolerabilidade do novo fármaco

Perfil Farmacocinético (processos de absorção, distribuição, biotransformação e eliminação dos fármacos; o que o organismo faz aos fármacos)

Perfil Farmacodinâmico (ações farmacológicas e mecanismos pelos quais os fármacos atuam; aquilo que os fármacos fazem ao organismo)

\section{População}

Voluntários saudáveis e por vezes indivíduos com patologia grave (Oncologia e SIDA) 20-80 pessoas

\section{Duração} Semanas
Fase II

Tipo de Estudo

Objetivos terapêuticos

Objetivo

Avaliação da Eficácia terapêutica

Determinação da dose e do regime terapêutico

Relação dose/resposta

Perfil de Segurança a curto prazo

Avaliação da terapêutica (Fase Ila), dose terapêutica apropriada (Fase IIb)

\section{População}

Número limitado de doentes

Doentes com a patologia ou a condição em estudo

Selecionados segundo critérios rigorosos População relativamente homogénea 25-100 pessoas

\section{Duração}

Semanas a meses 


\section{Fases dos Ensaios Clínicos}

Fase III

Tipo de Estudo

Objetivos terapêuticos Pré-AIM

Objetivo

Demonstração/confirmação do benefício terapêutico (ensaio comparativo)

Eficácia e Segurança

Obtenção de Autorização de Introdução no Mercado (AIM) - significância estatística População

População-alvo 200-10.000 pessoas

Duração

Meses a anos
Fase IV

Tipo de Estudo

Pós-AIM

Objetivo

Otimização do uso do medicamento

Avaliação de interações medicamentosas, efeitos adversos adicionais (farmacovigilância) Descrição de padrão de uso do medicamento Estudos de suporte ao Marketing Novas formulações

População

1000 a milhões de pessoas

Duração

Anos 


\section{Ética e segurança do doente}

É da responsabilidade do investigador a notificação adequada e atempada de todos os sinais, sintomas ou doenças ao longo do ensaio clínico, independentemente de estarem associados ao estudo ou à medicação, para além de constar no Processo Clínico do Doente.

Deve constar: Medicação Estudo, Nome Investigador, Identificação do Doente (№ Doente, data de nascimento, sexo), Termo evento, Avaliação da Causalidade e Relação com a medicação.

Mesmo os sinais ou sintomas que possam parecer não significativos, mais tarde podem revelar-se de extrema importância quando notificados em larga escala. Estas reações adversas são classificadas consoante a sua gravidade, a sua intensidade, ainda se são ou não esperadas, e se estão ou não relacionados com a medicação e/ou procedimento do estudo. 


\section{Ética e segurança do doente}

Todos os Acontecimentos Adversos Graves (SAEs) devem ser recolhidos e reportados a partir do momento que o doente assina o Consentimento Livre e Esclarecido ou Informado, e o Investigador tem que os reportar ao Promotor do Estudo, num período máximo de 24h após ter tomado conhecimento.

\section{https://www.mskcc.org/cancer-care/patient-education/understanding-informed-consent}

Um Acontecimento Adverso é considerado grave se:

Resultar em morte;

Colocar o doente em risco de vida;

Requerer ou prolongar a hospitalização;

Resultar em incapacidade temporária ou permanente;

Resultar em anomalias congénitas ou defeito à nascença;

For considerado medicamente importante.

Como pode ajudar?

https://www.youtube.com/watch?v=pjW1UiTp0G0 


\section{Segurança do doente em Unidades de Saúde}

\section{https://www.youtube.com/watch?v=6YMZFRhh9L4}

\section{https://www.youtube.com/watch?v=Td99SWUA060}

\section{EXERCÍCIOS}

Se fosse admitido para dirigir a segurança de pacientes num hospital, sobre o que se debruçaria?

Se estivesse a gerir um hospital e se fosse abordado pela indústria farmacêutica para a realização do estudo clínico de um novo fármaco para a obesidade nas suas instalações como procederia?

Como gestor de um hospital deve participar na farmacovigilância? Como? E como doente? Como? 


\title{
Como memorizar tudo o que aprendeu?
}

\author{
https://www.youtube.com/watch?v=mHdy1xS59xA
}




\section{Bibliografia}

- Armenian, HK; Shapiro, S. Epidemiology and health services. New York: Oxford University Press, 1998.

- Beaglehole, R; Bonita, R; Kjellström, T. Basic epidemiology. 2nd. ed. Geneva: World Health Organization; 2000.

- European Foundation Centre. Perspectivas europeias sobre saúde global: um glossário de politicas de saúde. Lisboa: Fundação Calouste Gulbenkian; 2007.

- Gillam, S., Yates, J. e Badrinath, P. Essential Public Health: Theory and Practice. Cambridge: Cambridge Medicine, 2012

- Last, John M, ed. A dictionary of public health. Oxford: Oxford University Press; 2007.

- Maxcy, Kenneth; Rosenau, MJ; Last, John M.; Wallace, Robert B., eds. Public health and preventive medicine. 14th ed. New Jersey: McGraw-Hill Professional; 1998.

- Shi, L. e Johnson, J. Novick \& Morrow's Public Health Administration. 3rd Revised edition. USA: Jones \& Bartlett Learning; 2013. 


\section{LINKS Úteis}

\section{SAúde PúBlica}

American Council on Science and Health

Autoridade de Segurança Alimentar e Económica - ASAE (vale a pena consultar, sobretudo a secção de Segurança

Alimentar)

BBC Health News

Centers for Disease Control and Prevention - CDC

CDC Emergency Preparedness \& Response (bioterrorismo, emergências em saúde pública, etc.)

CDC Public Health Laws News

Centre for Health Protection (Hong Kong - inglês e chinês)

CNN Health News

European Centre for Disease Control and Prevention - ECDC

European Antimicrobial Resistance Surveillance System - EARSS

European Food Information Resource Network - EuroFIR

European Food Safety Authority - EFSA

European Influenza Surveillance Scheme - EISS

European Network for Diagnostics of Imported Viral Diseases - ENIVD

European Network of Health Promotion and Public Health Agencies - EuroHealthNet

European Observatory on Health Systems and Policies

European Public Health Association - EUPHA

European Surveillance of Antimicrobial Consumption - ESAC

European Union Concerted Action on Lyme Borreliosis - EUCALB

European Union Invasive Bacterial Infections Surveillance Network - EUIBIS

European Working Group for Legionella Infections - EWGLI

Health Canada

Health EU - Public Health Thematic Portal 


\section{LINKS Úteis}

\section{SAÚde PúBLICA}

Health Protection Agency

Health Protection Surveillance Centre - HPSC Ireland

HIV/AIDS Surveillance in Europe - EuroHIV

Instituto Nacional de Saúde Dr. Ricardo Jorge

International Association of Public Health Institutes - IANPHI (espanhol, francês e inglês)

Inventory of Resources for Infectious Diseases in Europe - IRIDE

Johns Hopkins School of Public Health

National Institutes of Health - NIH

National Tuberculosis Center

Observatório Nacional de Saúde

Public Health Resources on the Internet

Public Health Topics

Saúde-UE (portal de saúde pública da União Europeia)

Saúde Pública - Europa

SIDA (informação em português sobre a epidemia em Portugal)

SIDA - John Hopkins School of Public Health

Surveillance Community Network for Vaccine Preventable Infectious Diseases - EUVAC

Surveillance of Tuberculosis in Europe - EuroTB

US Food and Drug Administration - FDA

World Health Organization - WHO 